\title{
The recombinant pseudorabies virus expressing African swine fever virus CD2v protein is safe and effective in mice
}

\author{
Zhihua Feng ${ }^{1}$, Jianghua Chen', Wangwang Liang ${ }^{1}$, Wenzhi Chen ${ }^{1}$, Zhaolong Li ${ }^{1}{ }^{2{ }^{*}}$, Qi Chen ${ }^{1 *}$ and Shaoli Cai ${ }^{{ }^{*}}$
}

\begin{abstract}
Background: African swine fever (ASF) leads to high mortality in domestic pigs and wild boar and is caused by the African swine fever virus (ASFV). Currently, no vaccine is commercially available for prevention, and the epidemic is still spreading. Here, we constructed a recombinant pseudorabies virus (PRV) (PRV- $\Delta g E / \Delta g l / \Delta T K-(C D 2 v))$ that expresses the CD2v protein of ASFV and evaluated its effectiveness and safety as a vaccine candidate in mice.

Methods: A homologous recombination fragment containing ASFV CD2 $\vee$ was synthesized and co-transfected into HEK 293 T cells, a knockout vector targeting the PRV TK gene. The transfected cells were infected with PRV- $\Delta g E / \Delta g l$, and the recombinant strain (PRV- $\triangle \mathrm{gE} / \Delta \mathrm{gl} / \Delta \mathrm{TK}$-(CD2v)) was obtained by plaque purification in Vero cells. The expression of ASFV CD2v in the recombinant virus was confirmed by sequencing, Western blotting, and immunofluorescence analysis, and the genetic stability was tested in Vero cells over 20 passages. The virulence, immunogenicity and protective ability of the recombinant virus were further tested in a mouse model.

Results: The PRV- $\triangle \mathrm{gE} / \Delta \mathrm{gl} / \Delta T K-(C D 2 v)$ recombinant strain is stable in Vero cells, and the processing of CD2v does not depend on ASFV infection. The vaccination of PRV- $\triangle \mathrm{gE} / \Delta \mathrm{gl} / \Delta \mathrm{TK}-(\mathrm{CD} 2 \mathrm{v})$ causes neither pruritus, not a systemic infection and inflammation (with the high expression of interleukin-6 (IL6)). Besides, the virus vaccination can produce anti-CD2v specific antibody and activate a specific cellular immune response, and 100\% protect mice from the challenge of the virulent strain (PRV-Fa). The detoxification occurs much earlier upon the recombinant virus vaccination and the amount of detoxification is much lower as well.

Conclusions: The PRV- $\triangle \mathrm{gE} / \Delta \mathrm{gl} / \Delta \mathrm{TK}-(\mathrm{CD} 2 \mathrm{v})$ recombinant strain has strong immunogenicity, is safe and effective, and maybe a potential vaccine candidate for the prevention of ASF and Pseudorabies.
\end{abstract}

Keywords: African swine fever virus, CD2v, Pseudorabies virus, vaccine, immunity

\section{Background}

African swine fever (ASF) is a highly contagious viral disease, a disease that must be reported to the World Organization for Animal Health (OIE) [1]. ASF was first reported in Kenya in 1921 [2], and then gradually

\footnotetext{
*Correspondence: 497377512@qq.com; chenqi@finu.edu.cn; 402247061@qq.com

${ }^{1}$ Fujian Key Laboratory of Innate Immune Biology, Biomedical Research Center of South China, Fujian Province, Fujian Normal University Qishan Campus, College Town, Fuzhou 350117, People's Republic of China

Full list of author information is available at the end of the article
}

spread to neighboring countries, in 2007-2017 to Georgia, Russia, Romania, and other European countries [3], and in 2018 to China, Mongolia, Vietnam, Cambodia, Laos, North Korea, and South Korea and other Asian countries $[4,5]$. The disease is caused by the ASF virus (ASFV), a double-stranded DNA virus with a large genome (170-193 kb) [6]. ASFV has 151-167 open reading frames (ORFs) and encodes 54 structural proteins and more than 100 non-structural proteins [7-10]. ASFV is the only known DNA arbovirus, has 24 genotypes and 8 serotypes, and sole member of the Asfarviridae family 
[10, 11]. A species of soft tick (Ornithodoros moubata) is the natural host of ASFV. The virulent ASFV strains can cause acute hemorrhagic fever and lead to up to $100 \%$ mortality in domestic pigs and wild boar (Sus scrofa) [6, 12]. Currently, there is no commercial vaccine to prevent ASF, and the epidemic is still spreading.

At present, various types of vaccines are under development to prevent ASF, including inactivated vaccines, live attenuated vaccines, subunit vaccines, DNA vaccines, virus vector vaccines, etc. Studies have shown that either traditional inactivated vaccines alone or with new adjuvants can produce specific antibodies but has no protective effect $[13,14]$. The single or combination of ASFV CD2v, P30, P54, and other subunit vaccines show some protective effects $[15,16]$. The "cocktail" immunization by using adenovirus vector vaccines carrying EP402R $\triangle \mathrm{PRR}, \mathrm{p} 54, \mathrm{p} 72$, and so on, and the recombinant B6461 (p72), EP153R and EP402R (CD2v) vaccinia virus vaccines can all induce strong humoral and cellular immunity $[17,18]$.

Cytotoxic T lymphocyte (CTL) immune response plays an important role in protecting ASFV [19]. Most DNA vaccines, such as a DNA vaccine expressing the ubiquitin (Ub)/CD2v/P54/P30 fusion protein, can effectively activate CTL immune response and provide partial protection after immunization in pigs $[20,21]$. A vaccine that contains 80 ORFs of ASFV (Ba71V) fused with ubiquitin can provide $60 \%$ protection after immunization, and the specific CTL immune response can be induced after the virus challenge [22]. Natural attenuated strains or improved live viruses show good protective effects, but most live attenuated vaccines only had a protective effect on the homologous strains [23-26]. Besides, most live attenuated vaccines lack high-yield cell lines. ASFV mainly infects the host monocyte-macrophage system through megapinocytosis and cytophagocytosis mediated by grid protein, and the production is low in the primary monocytes/macrophages [27, 28]. Besides, attenuated ASFV can produce adverse side effects, such as lymphadenopathy, recurrent fever, chronic viremia, persistent chronic infections and the possibility of virulence recovery [23]. These adverse factors hamper their development as usable vaccines. In contrast, subunit vaccines, DNA vaccines, and viral vector-based vaccines show advantages in terms of safety and productivity and are likely better options to be developed for preventing ASF.

Pseudorabies virus (PRV), Alphaherpesvirinae subfamily of the Herpesviridae, is the pathogen of swine Aujesz$k y$ 's disease, a double-stranded DNA virus with a genome size of $145 \mathrm{~kb}$. Domestic pigs and wild boars are the natural hosts of PRV $[29,30]$. PRV can infect pigs of all ages, but the symptoms appear different. Infection of PRV in adult pigs will lead to abortion and respiratory symptoms, while in piglets will lead to fatal encephalitis, which has caused huge economic losses in the global pig breeding industry [31]. Other mammals, such as rodents, can also be infected by PRV, and the host systemic inflammatory response, especially neuroinflammation, can cause severe itching and acute death in infected mice [32].

The PRV Bartha-K61 vaccine has been used to protect pigs from PRV infection. However, in recent years, a new PRV clade which belongs to the genotype II has been found in the pigs immunized with Bartha-K61, which belongs to genotype I. Thereby, the Bartha-K61 vaccine does not provide complete protection for the type II virus $[30,33]$ and new vaccines are needed to prevent the emergence of new epidemics. Several new vaccine strains, such as PRV $\mathrm{TK}^{-} / \mathrm{gE}^{-} / \mathrm{gI}^{-}$(Fa) [34], JS-2012$\Delta \mathrm{gE} / \mathrm{gI}$ [29], $\mathrm{gE}^{-} / \mathrm{gI}^{-} / \mathrm{TK}^{-}$PRV (HeN1) [35], have all showed good protection capabilities, and $\mathrm{PRV} \mathrm{TK}^{-} / \mathrm{gE}^{-} /$ $\mathrm{gI}^{-}(\mathrm{Fa})$ has been commercially used for the prevention of pseudorabies. PRV has more than 70 ORFs that encode 70-100 proteins, but only about 50 proteins are contained in mature virus particles. Many genes are unnecessary for PRV replication, such as TK, gE, and gI, which can be replaced by foreign genes [36-38]. Therefore, PRV is often used as a viral vector to carry foreign genes to develop recombinant vaccines. Many PRV recombinant strains, such as JS-2012- $\Delta$ gE/gI-E2 (expressing classical swine fever virus E2 protein) [39], PRV SA215/VP2 (expressing parvovirus VP12 protein) [40], PRV-P12A3C (expressing foot-and-mouth disease virus P12A and $3 \mathrm{C}$ proteins) [41], show good immunogenicity and safety.

The outer envelope protein CD2v of ASFV, encoded by the EP402R gene, is highly similar to the host CD2 protein in structure and function and is the key protein that mediates the ASFV binding with red blood cells and causes their adsorption [42]. ASFV infection can inhibit the proliferation of peripheral blood lymphocytes in vitro, which can be rescued by the EP402R gene deletion [43]. Deletion of CD2v can strongly inhibit ASFV proliferation by 100-1000 times in lymphoid tissue and bone marrow, and ameliorate viremia [43]. Thus, CD2v is likely to be involved in the immune escape, tissue phagocytosis of ASFV, and immunosuppressive effects. Blocking CD2v may revoke the host immunosuppressive effect, thereby enhancing the host's antiviral ability. CD2v has been developed as subunit, DNA, and virus vector vaccines, to provides partial protection $[15,20,44]$. At present, there is no report on the recombinant multivalent vaccine that recombinantly expresses the ASFV gene using PRV as a vector. In this study, we constructed a recombinant pseudorabies virus, PRV- $\Delta \mathrm{gE} / \Delta \mathrm{gI} / \Delta \mathrm{TK}$ $(\mathrm{CD} 2 \mathrm{v})$, that expresses the ASFV CD2v protein by using the CRISPR/Cas9 technology, and its safety and ability to 
produce humoral and cellular immune responses were evaluated in mice to provide evidence for the future vaccine development to prevent both African swine fever and Pseudorabies.

\section{Materials and methods}

\section{Cells, virus, and mouse}

All cell culture reagents were purchased from Life Technologies (CA, USA) unless otherwise indicated. Human embryonic kidney (HEK $293 \mathrm{~T}$ ) cells and Vero cells were cultured in Dulbecco's Modified Eagle Medium (DMEM) containing 10\% FBS (GIBCO), $100 \mathrm{U} / \mathrm{ml}$ penicillin, $100 \mathrm{mg} / \mathrm{ml}$ streptomycin, and $5 \% \mathrm{CO}_{2}$ at $37^{\circ} \mathrm{C}$. The peripheral blood lymphocytes of mice were cultured in RPMI 1640 medium. EXPi293 cells were purchased from Thermofisher (CA, USA) and cultured in a constant temperature shaker with OPM-293 CD03 medium under 8\% $\mathrm{CO}_{2}, 37^{\circ} \mathrm{C}, 220 \mathrm{rpm} / \mathrm{min}$. PRV was obtained from Fujian Academy of Agricultural Sciences (Fujian, China) and expanded in Vero cells. The viral titer was determined by the Karber method as follows: $2 \times 10^{4}$ Vero cells in $90 \mu \mathrm{l}$ DMEM were mixed with $10 \mu \mathrm{l}$ virus solution and plated onto 96-well plates for tenfold gradient dilution, and 8 multiple wells were set for each dilution gradient. The cytopathic effect was observed every $24 \mathrm{~h}$ until no change appeared in any well. The titer's calculation formula is $\lg \mathrm{TCID}_{50}=\mathrm{L}-\mathrm{D}(\mathrm{S}-0.5)$, where $\mathrm{L}$ is the logarithm of the highest dilution, $\mathrm{D}$ is the difference between the logarithm of dilution, and $S$ is the sum of the proportion of positive wells.

Four-week-old SPF-ICR mice were purchased from Wushi Experimental Animal Trade Co., Ltd (Jiangsu, China). The animal experiments were performed under the Guide for the Care and Use of Laboratory Animals approved by Fujian Provincial Office for Managing Laboratory Animals and were overseen by the Fujian Normal University Animal Care and Use Committee (SYXK: 2015-0004).

\section{Plasmids and viruses construction}

Construction of the knockout (KO) plasmids used the pX459 plasmid vector (purchased from Addgene, MA, USA, digest with BpiI $\left(37{ }^{\circ} \mathrm{C}, 15 \mathrm{~min}\right)$ (purchased from Thermo Fisher Scientific, MA, USA)) and sgRNA sequences (Table 1) targeting the PRV gE, gI and TK genes according to the website (https://www.e-crisp .org/e-crisp/designcrispr.html). After transformation into DH5 $\alpha$ E. coli, the recombinant plasmids were isolated and verified by sequencing.

The eukaryotic expression vector pcDNA3.4(N-CD2v)-His was constructed using pcDNA3.4 (purchased from Addgene, MA, USA). The extracellular region of $\mathrm{CD} 2 \mathrm{v}$ (46-615 bp, encoding 16-205aa)
Table 1 The sgRNA sequences target PRV-Fa gE, gl, TK genes

\begin{tabular}{ll}
\hline A. Primers name & B. sgRNA sequence 5'-3' $^{\prime}$ \\
\hline PRV-TK-sgRNA-F & 5'-caccgTGCCCGAGCCGATGGCGTGC-3' \\
PRV-TK-sgRNA-R & 5'-aaacGCACGCCATCGGCTCGGGCAc-3' \\
PRV-gE-sgRNA-F & 5'-accgGCCGGCGACGATGACCTCGA-3' \\
PRV-gE-sgRNA-R & 5'-aaacTCGAGGTCATCGTCGCCGGCc-3' \\
PRV-gl-sgRNA-F & 5'-caccgCGCGGGGTCGTACGTGCTGC-3' \\
PRV-gl-sgRNA-R & 5'-aaacGCAGCACGTACGACCCCGCGc-3' \\
\hline
\end{tabular}

Table 2 Primers for verifying viral genes mutation

\begin{tabular}{ll}
\hline A. Primers name & B. Primers sequence 5'-3' $^{\prime}$ \\
\hline PRV-TK-KO-F & 5'-TCGTAGAAGCGGTTGTGG-3' \\
PRV-TK-KO-R & 5'-CGACCAGGACGAACAGG-3' \\
PRV-gE-KO-F & 5'-AAAAGGTGGTGTTTGCATAATT-3' \\
PRV-gE-KO-R & 5'-TCGGTGGTGATGTAGAACG-3' \\
PRV-gl-KO-F & 5'-GTGGGCGTGTGCGTCTA-3' \\
PRV-gl-KO-R & 5'-CGGACGGAGATAAAACGC-3' \\
\hline
\end{tabular}

synthesized by the Wuhan GeneCreate Biological Engineering (Hubei, China) was inserted into pcDNA3.4 and fused with the His-tag at the C-terminus. The fulllength CD2v gene (based on pig/HLJ/2018 [1] strain) was synthesized by Wuhan GeneCreate Biological Engineering (Hubei, China) and used to make pcDNA3.1EGFP-Flag-CD2v-Flag. The recombinant vectors were transformed into E. coli DH5 $\alpha$ (DE3). All plasmids were extracted using a kit (DP118-02) purchased from TIANGEN BIOTECH (Beijing, China).

To generate gene-deleted PRVs, the $\mathrm{KO}$ plasmids targeting PRV gE, gI, TK were transfected into $5 \times 10^{5}$ HEK $293 \mathrm{~T}$ cells. Six $\mathrm{h}$ after transfection, $1 \times 10^{5}$ $\mathrm{TCID}_{50}$ PRV-Fa was added. The virus culture was harvested when the cytopathic effect reached $90 \%$ or more. The sgRNA-induced mutation was determined by PCR and sequencing by the primers as shown in Table 2 . Four rounds of plaque purification were performed in Vero cells to obtain pseudorabies gE, gI double gene deletion strain PRV- $\Delta \mathrm{gE} / \Delta \mathrm{gI}$ and $\mathrm{gE}$, gI, TK triple gene deletion strain PRV- $\Delta \mathrm{gE} / \Delta \mathrm{gI} / \Delta \mathrm{TK}$.

To generate recombinant PRV (PRV- $\Delta \mathrm{gE} / \Delta \mathrm{gI} / \Delta \mathrm{TK}$ $(\mathrm{CD} 2 \mathrm{v})), 5 \mu \mathrm{g}$ of plasmid and $1 \mu \mathrm{g}$ of the homologous recombinant fragment were co-transfected into HEK $293 \mathrm{~T}$ cells. Six h after transfection, $5 \times 10^{5} \mathrm{TCID}_{50}$ of $\mathrm{PRV}-\Delta \mathrm{gE} / \Delta \mathrm{gI}$ was added. The virus culture was harvested when $90 \%$ of the cells were assured of having cytopathic effects. Finally, the recombinant PRV- $\Delta \mathrm{gE} /$ $\Delta \mathrm{gI} / \Delta \mathrm{TK}-(\mathrm{CD} 2 \mathrm{v})$ strain expressing ASFV $\mathrm{CD} 2 \mathrm{v}$ was 
amplified and purified in Vero cells by four rounds of phagocytosis.

\section{Immunofluorescence}

HEK $293 \mathrm{~T}$ cells $\left(2 \times 10^{5}\right)$ were cultured for $24 \mathrm{~h}$, and transfected with pcDNA3.1-EGFP-Flag-CD2v-Flag or infected with $5 \times 10^{4} \mathrm{TCID}_{50}$ viruses for $36 \mathrm{~h}$. The cells were fixed with $1 \mathrm{ml} 4 \%$ paraformaldehyde, penetrated with $1 \mathrm{ml} \mathrm{0.1 \%}$ Triton X-100 (Sangon Biotech, Shanghai, China), incubated by mouse anti-Flag monoclonal antibody (TransGen Biotech, China) followed by Goat anti-mouse IgG H \& L (Alexa fluor ${ }^{\circledR} 488$ ) preadsorbed (ab150117), and the images were obtained by scanning with ZEISS LSM700 microscope.

\section{Western blot analysis}

HEK $293 \mathrm{~T}$ cells were cultured for $24 \mathrm{~h}$, and transfected with the plasmid pcDNA3.1-EGFP-Flag-CD2v-Flag or infected with $1 \times 10^{6} \mathrm{TCID}_{50}$ of PRV- $\Delta \mathrm{gE} / \Delta \mathrm{gI} / \Delta \mathrm{TK}-$ $(\mathrm{CD} 2 \mathrm{v})$. Samples were collected $48 \mathrm{~h}$ after transfection or viral infection. The protein concentration was determined by a BCA protein concentration test kit (from Beyotime Biotechnology, Shanghai, China)). Sixty $\mu$ g of proteins were loaded for SDS-polyacrylamide gel electrophoresis and transferred to the PVDF membrane. The membrane was sealed with $5 \%$ skim milk at room temperature for $2 \mathrm{~h}$, then incubated with the mouse anti-Flag monoclonal antibody (1:1000 dilution, ProteinFind ${ }^{\circledR}$ Anti-DYKDDDDK Mouse Monoclonal Antibody HT201-01 (TransGen Biotech, (Beijing, China)) or GAPDH (14C10) Rabbit mAb (Cell Signaling Technology, USA) in $5 \%$ skimmed milk plus $100 \mathrm{mg} / \mathrm{L} \mathrm{NaN}_{3}$ at $4{ }^{\circ} \mathrm{C}$ for $8 \mathrm{~h}$, washed with TBST buffer for 3 times, followed by incubation with secondary antibody IRDye $800 \mathrm{cw}$ donkey anti-mouse IgG (LI-COR) $(1: 10,000)$ at room temperature for $2 \mathrm{~h}$. The membrane was washed with TBST and visualized by using LI-COR Odyssey infrared fluorescence scanning imager.

\section{Virus growth and pathogenicity analyses}

To determine the growth kinetics of the virus, $5 \times 10^{5}$ Vero cells in $2 \mathrm{ml}$ DMEM were seeded onto each well of 6 -well plates, $1 \times 10^{3} \mathrm{TCID}_{50}$ viruses was added into each well, and the sample was collected at 12, 24, 36, $48 \mathrm{~h}$ post-infection, and virus titer was calculated by the Karber method.

The growth of plaques in Vero cells was observed by doubled-blinded crystal violet staining. Vero cells $\left(5 \times 10^{5} /\right.$ each well $)$ in the 6-well plates were infected with PRV-Fa, PRV- $\Delta \mathrm{gE} / \Delta \mathrm{gI} / \Delta \mathrm{TK}, \mathrm{PRV}-\Delta \mathrm{gE} / \Delta \mathrm{gI} / \Delta \mathrm{TK}-(\mathrm{CD} 2 \mathrm{v})$ of $50 \mathrm{TCID}_{50}$ for $48 \mathrm{~h}$, and fixed with $4 \%$ paraformaldehyde for $30 \mathrm{~min}$, stained with $2.5 \%$ crystal violet. Ten plaques were randomly selected to measure their areas under the microscope.

For the pathogenicity test, 4-week-old SPF grade ICR mice were fed adaptively for 1 week. The survival of mice was observed by injecting $5 \times 10^{5} \mathrm{TCID}_{50}$ into the right hind leg muscle, and the survival curve was drawn accordingly.

\section{(N-CD2v)-His purification}

The EXPi 293 cells were transfected with pcDNA3.4-(NCD2v)-His plasmid, collected after 7 days of culture, and lysed with RIPA (about $500 \mu \mathrm{l}$ of RIPA per $1 \times 10^{7}$ cells). The $(\mathrm{N}-\mathrm{CD} 2 \mathrm{v})-\mathrm{His}$ protein was enriched with a nickel column and eluted with Elution Buffer (300 mM imidazole, $1 \mathrm{mM}$ PMSF, $25 \mu \mathrm{l} \beta$-mercaptoethanol). The eluate was vacuum dried, dissolved in PH7.4 PBS, and used for SDS polyacrylamide gel electrophoresis. The purity of the recombinant protein was determined by Coomassie staining.

\section{Virus copy analyses in mice}

When the control PRV-Fa-infected mice group began to scratch (about $72 \mathrm{~h}$ postinoculation), the mice in all groups were euthanized by $\mathrm{CO}_{2}$ inhalation. The heart, brain, lung, liver, spleen and kidney tissues were collected, and the corresponding DNA was extracted. Realtime quantitative polymerase chain reaction (qPCR) was used to determine viral genome copies in infected cells and tissues. The PRV UL42 gene was used for standard control and was inserted into the $\mathrm{pCDH}$ plasmid to make pCDH-UL42. The UL42 gene was also amplified from the genomic DNA of the PRV-Fa strain using the forward primer $5^{\prime}$-ATGTCGCTGTTCGACGAC-3' and the reverse primer $5^{\prime}$-TTAGAATAAATCTCCGTAGGCG$3^{\prime}$. Viral and tissue genomic DNA was extracted and purified by using a DNA Extraction Kit DP304 (TIANGEN BIOTECH (BEIJING)), and the PCR products were purified using FastPure Gel DNA Extraction Mini Kit DC301 (Vazyme Biotech, Jiangsu, China).

The virus copy number was also examined in feces. The feces of mice were picked up every $24 \mathrm{~h}$ after the virus challenge. One gram of feces was mixed with $5 \mathrm{ml}$ of phosphate buffer saline (PBS) and soaked for $2 \mathrm{~h}$, and the supernatant was collected by centrifugation at $3000 \mathrm{~g}$ for $10 \mathrm{~min}$ and used for extracting the genome DNA for qPCR determination of virus nucleic acid copies. The primers were: forward (5'-AACGTCACCTTCGAGGTG TA-3') and reverse (5'-AGTCTGAACTCGTGCTTG- $3^{\prime}$ ).

The virus copy number was calculated as follows: the average molecular weight (Dalton) of pCDH-UL42 = base number $\times 600$ (Base pair average molecular weight), the length of pCDH-UL42 $=8542 \mathrm{bp}(\mathrm{pCDH})+1158 \mathrm{bp}$ $(\mathrm{PRV}-\mathrm{UL} 42)=9700 \mathrm{bp}$, and the copy number of $1 \mathrm{ng}$ 
$\mathrm{pCDH}-\mathrm{UL} 42=6.02 \times 10^{23} \times\left(1 \times 10^{-9} /(9700 \times 600)\right)$ $\approx 1.0 \times 10^{8}$. The standard curve was generated using the copy number of pCDH-UL42 as the ordinate, and the $\mathrm{CT}$ values determine the corresponding $\mathrm{CT}$ value as the abscissa and the copy number of the PRV genome.

\section{Cytokine expression analyses in mice}

The heart, brain, lung, liver, spleen and kidney tissues from the virus-infected mice were collected, and the total RNA was extracted. The RNA was extracted using Trizol Gamma Reagent (Thermo Fisher Scientific, CA, USA). cDNA was generated by reverse transcription using MonScript $^{\mathrm{TM}}$ RTII All-in-One Mix with dsDNase Kit (Mona Biotech, Jiangsu, China) according to the manufacturer's instruction. The RNA expression of cytokines (see Table 3 for cytokine primers) was analyzed by reverse transcription qPCR.

For testing interferon- $\gamma$ (IFN $\gamma$ ), on day 7 after mice second immunization, peripheral blood lymphocytes (PBMCs) were obtained by collecting $1 \mathrm{ml}$ of cardiac blood following the treatment with red cell lysate (Beyotime Biotechnology, China). PBMCs $\left(1 \times 10^{6}\right)$ were cultured for $12 \mathrm{~h}$ and treated with $10 \mu \mathrm{g}$ recombinant protein $(\mathrm{N}-\mathrm{CD} 2 \mathrm{v})$-His for $72 \mathrm{~h}$. The cells were then harvested, and the IFN $\gamma$ transcription level was measured by qRT-PCR. The primers used for analyses were: IFNYForward (5'-GCCACGCACAGTGATTGA-3'); IFNYReverse (5'-TGCTGATGCCTGATTTGTCTT-3').

\section{Flow cytometry analysis of CD3/CD4/CD8/CD69 peripheral blood lymphocytes}

When the control PRV-Fa group began to scratch (about $72 \mathrm{hpi}$ ), about $300 \mu \mathrm{l}$ of blood was collected from the mouse orbit for analyses of $\mathrm{CD}^{+}, \mathrm{CD}^{+} \mathrm{CD}^{+}$, $\mathrm{CD}^{+} \mathrm{CD}^{+}, \mathrm{CD}^{+} \mathrm{CD} 69^{+}, \mathrm{CD}^{+}{ }^{+} \mathrm{CD} 69^{+}, \mathrm{CD}^{+} \mathrm{CD}^{+} 9^{+}$ peripheral blood lymphocytes by flow cytometry. Two hundred $\mu$ l of blood was mixed with $1 \mu$ l of antibody (BV421 Hamster Anti-Mouse CD3e, FITC Rat AntiMouse CD4, PerCP-CY 5.5 Rat Anti-Mouse CD8 $\alpha$, PE

Table 3 Primers for RT-qPCR

\begin{tabular}{|c|c|}
\hline A. Primers name & B. Primers sequence $5^{\prime}-3^{\prime}$ \\
\hline MUS-IL6-q-PCR-F & 5'-CTGCAAGAGACTTCCATCCAG-3' \\
\hline MUS-IL6-q-PCR-R & 5'-AGTGGTATAGACAGGTCTGTTGG-3' \\
\hline MUS-IL1 $\beta-q-P C R-F$ & 5'-GAAATGCCACCTTTTGACAGTG-3' \\
\hline MUS-IL1 $\beta-q-P C R-R$ & 5'-TGGATGCTCTCATCAGGACAG-3' \\
\hline MUS-TNFa-q-PCR-F & 5'-CAGGCGGTGCCTATGTCTC-3' \\
\hline MUS-TNFa-q-PCR-R & 5'-CGATCACCCCGAAGTTCAGTAG-3' \\
\hline MUS-IFNß-q-PCR-F & 5'-AGCTCCAAGAAAGGACGAACA-3' \\
\hline MUS-IFNß-q-PCR-R & 5'-GCCCTGTAGGTGAGGTTGAT-3' \\
\hline
\end{tabular}

Hamster Anti-Mouse CD69 (BD pharmaceuticals, CA, USA) for $30 \mathrm{~min}$ in the dark at $25{ }^{\circ} \mathrm{C}$, incubated with $600 \mu \mathrm{l}$ of RBC lysate (Shanghai Biyuntian Biotechnology, China) for $5 \mathrm{~min}$. The cells were collected by centrifugation and suspended in PBS containing 2\% FBS followed by flow cytometry analyses (BD FACSymphony ${ }^{\text {TM }}$ A5, BD Bioscience, CA, USA).

\section{Immunization and challenge}

Five-week-old SPF mice (ICR) were injected with either $\mathrm{PRV}-\Delta \mathrm{gE} / \Delta \mathrm{gI} / \Delta \mathrm{TK} \quad$ or $\quad \mathrm{PRV}-\Delta \mathrm{gE} / \Delta \mathrm{gI} / \Delta \mathrm{TK}-(\mathrm{CD} 2 \mathrm{v})$ $\left(100 \mu \mathrm{l}\right.$ each, $\left.1 \times 10^{5} \mathrm{TCID}_{50}\right)$ via the $i . m$. route, and strengthened by the second immunization one week later. Seven days later, the mice were challenged by PRVFa with $5 \times 10^{5} \mathrm{TCID}_{50}$. The control group was injected with $100 \mu \mathrm{L}$ DMEM.

\section{Enzyme-linked immunosorbent assay (ELISA) for Flag IgG}

About $300 \mu \mathrm{l}$ of blood was collected from the mouse orbit 0,7 and 14 days after the first immunization. The supernatant was collected by centrifugation at $3000 \mathrm{rpm} /$ min for 5 min after the blood was placed at room temperature for $10 \mathrm{~min}$, and used for detecting the Flag IgG by ELISA using SBJ-M0915-96 T Flag-tag AB ELISA Kit (SenBeiJia Biological Technology, Jiangsu, China).

\section{Hematoxylin-Eosin staining}

Mouse tissues were fixed with $4 \%$ paraformaldehyde for $12 \mathrm{~h}$. The samples were treated with $30 \%$ ethanol, $50 \%$ ethanol, $70 \%$ ethanol, $90 \%$ ethanol, $95 \%$ ethanol and anhydrous ethanol for $30 \mathrm{~min}$ each, followed by transparent treatment with the mixture of ethanol and xylene (1:1), and xylene to replace the ethanol in the tissues. The tissues were treated with a mixture of paraffin and xylene (1:1) overnight, then embedded into the paraffin. The tissues were cut to the $7 \mu \mathrm{m}$ slices followed by staining with hematoxylin and eosin, and the morphological changes were checked by Zeiss Axio Imager A2/D2/m2/Z2.

\section{Data statistical analysis and image processing}

Images for Western blotting, H\&E staining, crystal violet staining and immunofluorescence were processed by Adobe Illustrator CS6, and the sequence data were analyzed by BioEdit. All experiments were repeated at least 3 times independently. Unpaired $t$-test or two-way ANOVA (Graphpad Prism 5.0, Graphpad Software, San Diego, CA, USA) was used to analyze data differences between groups. Data are presented as the mean \pm SEM in the same treatment. 


\section{Results}

\section{Generation of the recombinant pseudorabies virus} PRV- $\Delta \mathrm{gE} / \Delta \mathrm{gl} / \Delta \mathrm{TK}-(\mathrm{CD} 2 \mathrm{v})$

The recombinant pseudorabies virus PRV- $\Delta \mathrm{gE} / \Delta \mathrm{gI} / \Delta \mathrm{TK}-$ (CD2v) expressing ASFV CD2v protein was constructed by homologous recombination using the CRISPR/Cas9 technology. As shown in Fig. 1a, the EGFP was driven by the CMV promoter, and the CD2v was driven by the EF1 $\alpha$ promoter. The recombinant fragment was inserted into the $\mathrm{N}$-terminus of the PRV- $\Delta \mathrm{gE} / \Delta \mathrm{gI}$ UL23 (TK) gene to construct PRV- $\Delta \mathrm{gE} / \Delta \mathrm{gI} / \Delta \mathrm{TK}-(\mathrm{CD} 2 \mathrm{v})$, in which the TK gene was disabled. The PRV- $\Delta \mathrm{gE} / \Delta \mathrm{gI} / \Delta \mathrm{TK}$ and $\mathrm{PRV}-\Delta \mathrm{gE} / \Delta \mathrm{gI} / \Delta \mathrm{TK}-(\mathrm{CD} 2 \mathrm{v})$ mutations were sequenced as shown in Fig. 1b, c. CD2v was successfully expressed in HEK 293 T cells, as shown by immunostaining (Fig. 1d) and Western blotting (Fig. 1e). CD2v can be expressed in HEK $293 \mathrm{~T}$ cells either by pcDNA3.1-EGFP-FlagCD2v-Flag transfection or PRV- $\Delta \mathrm{gE} / \Delta \mathrm{gI} / \Delta \mathrm{TK}-(\mathrm{CD} 2 \mathrm{v})$ infection. Transfection with pcDNA3.1-EGFP-FlagCD2v-Flag CD2v mainly shows the expression of the 26 KD C-terminus and $19 \mathrm{KD} \mathrm{N}$-terminus cleaved proteins, while infection with PRV- $\Delta \mathrm{gE} / \Delta \mathrm{gI} / \Delta \mathrm{TK}-(\mathrm{CD} 2 \mathrm{v})$ resulted in the expression of the glycosylated $89 \mathrm{KD}$ full length and glycosylated $45 \mathrm{KD}$ N-terminus fragment, and the 26 KD C-terminus fragment (Fig. 1e). As expected, CD2v was not expressed in HEK $293 \mathrm{~T}$ cells transfected with pcDNA3.1 or infected with PRV- $\Delta \mathrm{gE} / \Delta \mathrm{gI} / \Delta \mathrm{TK}$. These results indicate that the recombinant pseudorabies strain PRV $-\Delta \mathrm{gE} / \Delta \mathrm{gI} / \Delta \mathrm{TK}-(\mathrm{CD} 2 \mathrm{v})$ was successfully constructed and $C D 2 v$ processing is independent of ASFV infection.

\section{The recombinant strain can proliferate well in vitro and is safe for mice}

The proliferation of PRV- $\Delta \mathrm{gE} / \Delta \mathrm{gI} / \Delta \mathrm{TK}-(\mathrm{CD} 2 \mathrm{v})$ was tested in the infected Vero cells. PRV- $\Delta \mathrm{gE} / \Delta \mathrm{gI} / \Delta \mathrm{TK}$ $(\mathrm{CD} 2 \mathrm{v})$ and $\mathrm{PRV}-\Delta \mathrm{gE} / \Delta \mathrm{gI} / \Delta \mathrm{TK}$ were far less capable of infecting the Vero cells compared with PRV-Fa at the designated concentrations (Fig. $2 \mathrm{a}-\mathrm{C}$ ). The proliferative ability between PRV- $\Delta \mathrm{gE} / \Delta \mathrm{gI} / \Delta \mathrm{TK}-(\mathrm{CD} 2 \mathrm{v})$ and PRV$\Delta \mathrm{gE} / \Delta \mathrm{gI} / \Delta \mathrm{TK}$ was not significantly different in Vero cells (Fig. 2c), suggesting that CD2v does not change the virus growth dynamics in vitro. Then, we used mice to evaluate the safety of the recombinant strains. As shown in Fig. 2d, all mice in the PRV-Fa-infected group died on the 5th day of inoculation, while the mice infected with either PRV$\Delta \mathrm{gE} / \Delta \mathrm{gI} / \Delta \mathrm{TK}$, or PRV- $\Delta \mathrm{gE} / \Delta \mathrm{gI} / \Delta \mathrm{TK}-(\mathrm{CD} 2 \mathrm{v})$ did not die until the 14th day. We observed severe pruritus in the PRV-Fa group on the 3rd day following inoculation, but not in PRV- $\Delta \mathrm{gE} / \Delta \mathrm{gI} / \Delta \mathrm{TK}$ or PRV- $\Delta \mathrm{gE} / \Delta \mathrm{gI} / \Delta \mathrm{TK}-(\mathrm{CD} 2 \mathrm{v})$ infected groups (Additional file 1: Figure S1), suggesting that the insertion of $C D 2 \mathrm{v}$ does not change the pathogenicity of PRV- $\Delta \mathrm{gE} / \Delta \mathrm{gI} / \Delta \mathrm{TK}$.
The virulent effect of CD2v was also tested by lethality, tissue pathology, expression of inflammatory factors and tissue inflammation in the mice infected with PRVFa, $\quad$ PRV $-\Delta \mathrm{gE} / \Delta \mathrm{gI} / \Delta \mathrm{TK}, \quad \mathrm{PRV}-\Delta \mathrm{gE} / \Delta \mathrm{gI} / \Delta \mathrm{TK}-(\mathrm{CD} 2 \mathrm{v})$ at the designated concentrations. By qPCR and qRTPCR, we examined the viral copy number and the IL6, Tumor necrosis factor- $\alpha$ (TNF $\alpha)$, Interleukin1- $\beta$ (IL1 $\beta)$; Interferon- $\beta$ (IFN $\beta$ ) transcription levels in the brain, heart, lung, liver, kidney, and spleen tissues of infected mice. The viral genome DNA was detected in all tissues in PRV-Fa-infected mice, but not in PRV- $\Delta \mathrm{gE} / \Delta \mathrm{gI} /$ $\Delta \mathrm{TK}$ or $\mathrm{PRV}-\Delta \mathrm{gE} / \Delta \mathrm{gI} / \Delta \mathrm{TK}-(\mathrm{CD} 2 \mathrm{v})$ infected group at 72 hpi (Fig. 3a-f). When the infection time was extended to $200 \mathrm{~h}$, viral nucleic acid was detected in the brain and lungs of mice infected with PRV $-\Delta \mathrm{gE} / \Delta \mathrm{gI} / \Delta \mathrm{TK}$ or PRV- $\Delta \mathrm{gE} / \Delta \mathrm{gI} / \Delta \mathrm{TK}-(\mathrm{CD} 2 \mathrm{v})$ (Fig. $3 \mathrm{~g}-\mathrm{h})$. However, the copy number of the virus is very low compared with the PRV-Fa infection at $72 \mathrm{hpi}$. These results indicate that the insertion of CD2v does not change the histopathology of PRV $-\Delta \mathrm{gE} / \Delta \mathrm{gI} / \Delta \mathrm{TK}$. The sensitivity of qPCR for detecting virus copies is shown in Additional file 2: Figure S2, S2A is the pCDH-UL42 plasmid map, Additional file 2: Figure $\mathrm{S} 2 \mathrm{~B}$ is the amplification curve, and Additional file 2: Figure S2C is the calibration equation as $\mathrm{Y}=-0.2425 \mathrm{X}+9.2678\left(\mathrm{R}^{2}=0.994\right)$, Additional file 2 : Figure S2D is a gel electrophoresis image of the qPCR product. According to Additional file 2: Figure S2B and S2D, the limit for virus copy detection by qPCR is between 10 to 100 .

PRV-Fa infection can lead to a large increase in the IL6 mRNA expression, whereas inoculation of PRV- $\Delta \mathrm{gE} / \Delta \mathrm{gI} /$ $\Delta \mathrm{TK}$ or $\mathrm{PRV}-\Delta \mathrm{gE} / \Delta \mathrm{gI} / \Delta \mathrm{TK}-(\mathrm{CD} 2 \mathrm{v})$ did not cause upregulation of IL6 expression (Fig. 4a). But, inoculation of each of these 3 virus strains did not cause changes in TNF $\alpha$, IL1 $\beta$, IFN $\beta$ transcription levels (data not shown). Consistently, the ELISA data showed a large increase in the IL6 protein in the serum of PRV-Fa infected mice, but not in the PRV- $\Delta \mathrm{gE} / \Delta \mathrm{gI} / \Delta \mathrm{TK}$ or $\mathrm{PRV}-\Delta \mathrm{gE} / \Delta \mathrm{gI} /$ $\Delta \mathrm{TK}-(\mathrm{CD} 2 \mathrm{v})$ group as compared to the control uninfected group (Fig. 4b). H \& E staining showed that PRVFa induced inflammatory cells' infiltration in the brain, but not in the other two infected groups (Fig. 4c). All the above data indicate that $C D 2 v$ expression does not change the virulence of PRV- $\Delta \mathrm{gE} / \Delta \mathrm{gI} / \Delta \mathrm{TK}$, and PRV$\Delta \mathrm{gE} / \Delta \mathrm{gI} / \Delta \mathrm{TK}-(\mathrm{CD} 2 \mathrm{v})$ is as safe as $\mathrm{PRV}-\Delta \mathrm{gE} / \Delta \mathrm{gI} / \Delta \mathrm{TK}$.

\section{Recombinant strains can induce specific humoral and T cell immune responses in a mouse model}

We evaluate the possible immune effects of the recombinant virus strains. The spleen was significantly heavier in the mice infected by PRV $-\Delta \mathrm{gE} / \Delta \mathrm{gI} / \Delta \mathrm{TK}$ or PRV $-\Delta \mathrm{gE} /$ $\Delta \mathrm{gI} / \Delta \mathrm{TK}-(\mathrm{CD} 2 \mathrm{v})$ than that of the control untreated group (Fig. 5a,b). There was no difference in spleen 


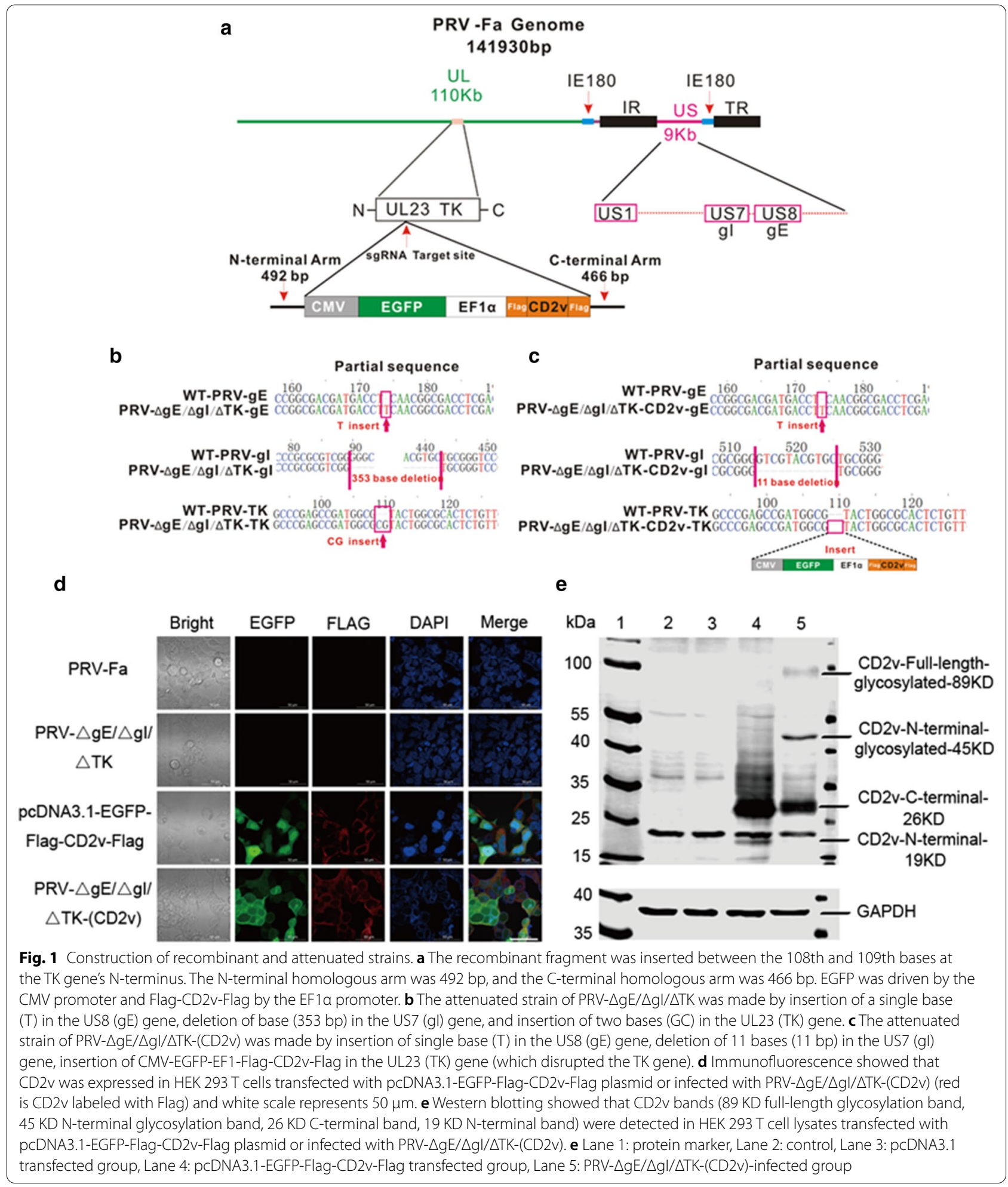

weight between the immunized and control groups at 200 hpi (Additional file 3: Figure S3). H \& E staining showed a significant infiltration of lymphocytes in spleen tissues of PRV- $\Delta \mathrm{gE} / \Delta \mathrm{gI} / \Delta \mathrm{TK}$ or $\mathrm{PRV}-\Delta \mathrm{gE} / \Delta \mathrm{gI} /$ $\Delta \mathrm{TK}-(\mathrm{CD} 2 \mathrm{v})$ infected mice, but no difference was seen between the PRV-Fa group and control group (Fig. 5c). 


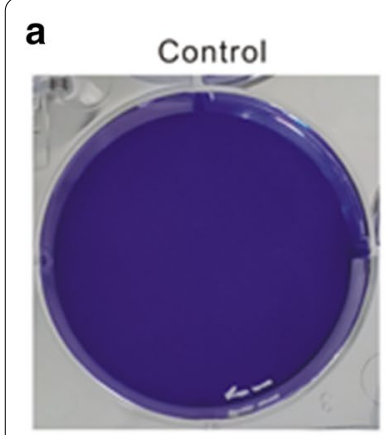

PRV- $\Delta \mathrm{gE} / \Delta \mathrm{gI} / \Delta \mathrm{TK}$
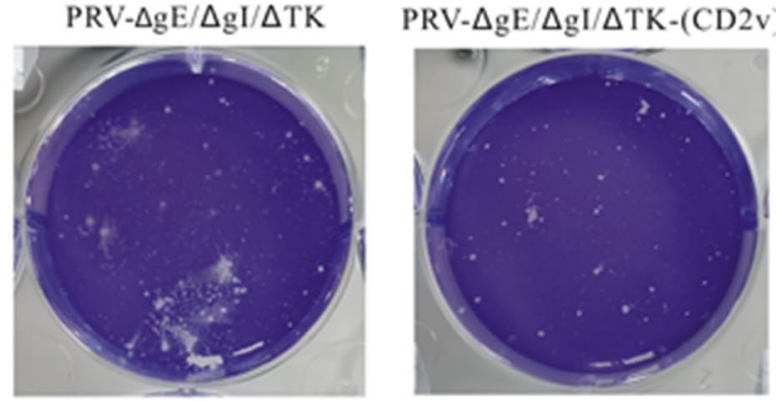

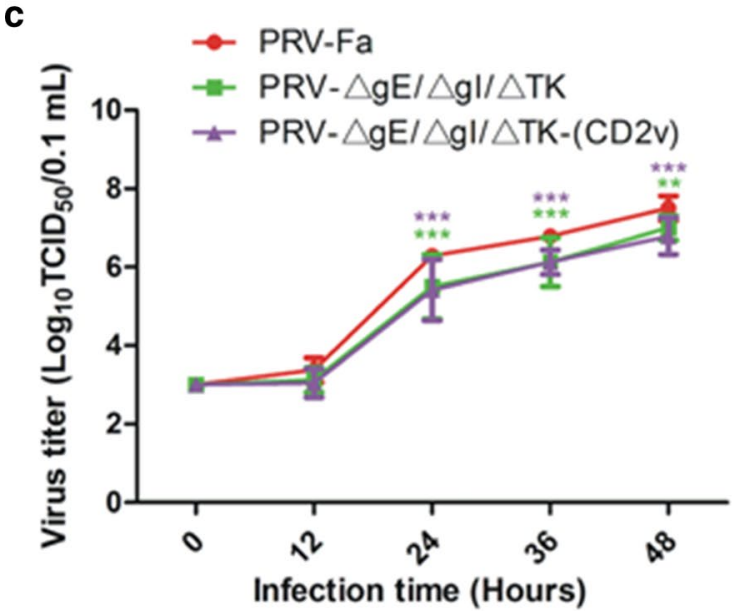

\section{b}

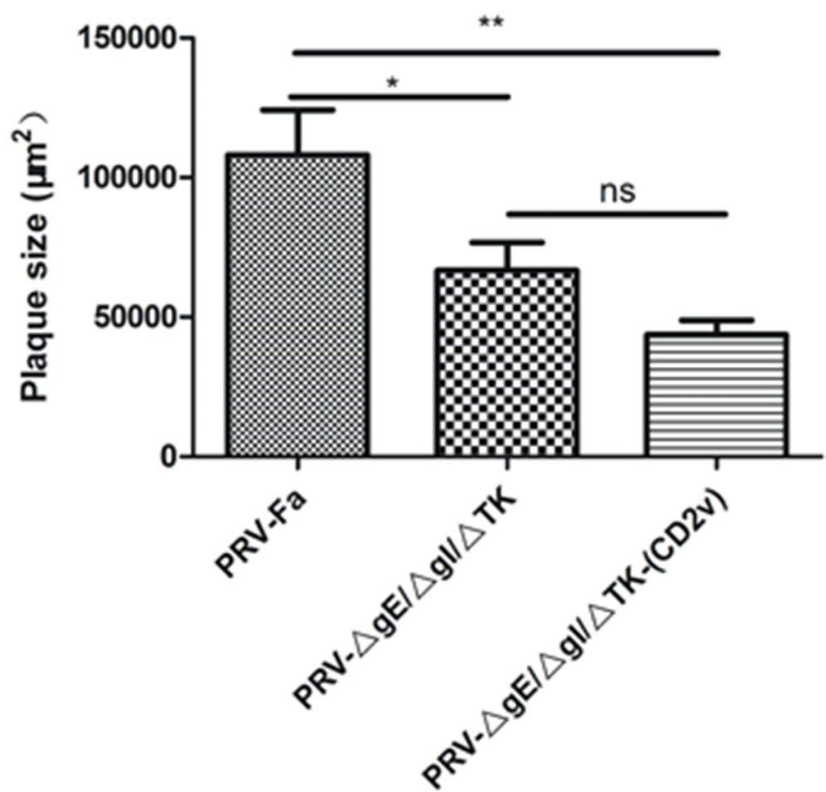

d

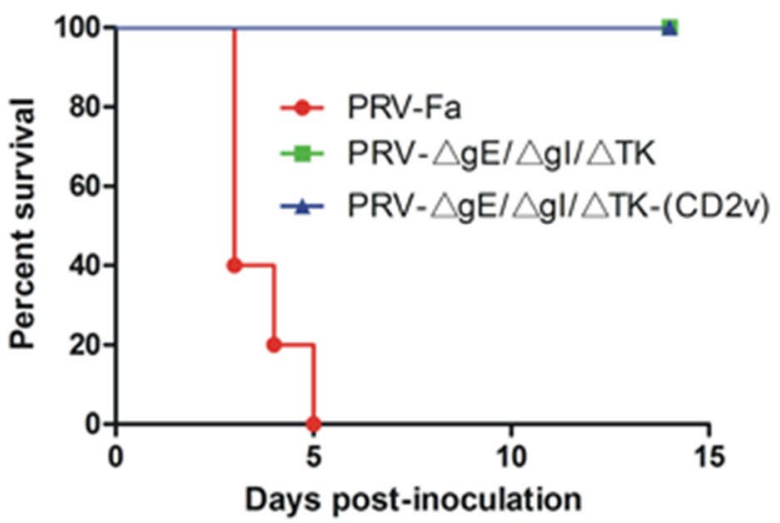

Fig. 2 The insertion of CD2v did not change the proliferation and virulence of PRV- $\triangle \mathrm{gE} / \Delta \mathrm{gl} / \Delta T \mathrm{TK}$. $\mathbf{a}$ The $50 \mathrm{TCID} 50$ virus was inoculated into $5 \times 10^{5}$ Vero cells and cultured for $48 \mathrm{~h}$. The growth of plaques in Vero cells was observed by crystal violet staining. $\mathbf{b}$ Statistical results of the plaque area. c $1 \times 10^{3} \mathrm{TCID} 50$ viruses were inoculated into $5 \times 10^{5}$ Vero cells to allow virus proliferation, and the virus sample was collected at $12 \mathrm{~h}, 24 \mathrm{~h}, 36 \mathrm{~h}$, $48 \mathrm{~h}$. The virus titer was calculated by the Karber method to draw a one-step growth curve. $\mathbf{d}$ Five-week-old SPF ICR mice were injected (i.m) with $5 \times 10^{5} \mathrm{TCID} 50$ viruses into the right hind leg to observe mice's survival daily, and the survival curve was drawn ( $n=15 /$ each group). Unpaired t-test or two-way ANOVA was performed by GraphPad Prism 5.0, GraphPad Software (San Diego, CA, USA), ${ }^{*} p<0.05,{ }^{* *} p<0.01,{ }^{* * *} p<0.001$, ns (not significant)

The percentage of $\mathrm{CD}^{+}, \mathrm{CD}^{+} \mathrm{CD}^{+}, \mathrm{CD}^{+} \mathrm{CD}^{+}$cells in PBMCs of mice is shown in Fig. 6. The percentage of $\mathrm{CD}^{+} \mathrm{T}$ cells in mouse PBMCs increased significantly by the inoculation with PRV- $\Delta \mathrm{gE} / \Delta \mathrm{gI} / \Delta \mathrm{TK}$ or PRV- $\Delta \mathrm{gE} /$ $\Delta$ gI $\Delta$ TK- $(\mathrm{CD} 2 \mathrm{v})(P<0.01, P<0.01)$ (Fig. 6e). However, compared with PRV- $\Delta \mathrm{gE} / \Delta \mathrm{gI} / \Delta \mathrm{TK}, \mathrm{PRV}-\Delta \mathrm{gE} / \Delta \mathrm{gI} / \Delta \mathrm{TK}-$ $(\mathrm{CD} 2 \mathrm{v})$ has a weaker ability to induce $\mathrm{T}$ cell proliferation in the early stage of infection (72 hpi) (Fig. 6e). Further analysis of $\mathrm{CD}^{+} \mathrm{CD}^{+}$and $\mathrm{CD} 3^{+} \mathrm{CD} 8^{+} \mathrm{T}$ cell subtypes found that recombinant strain could inhibit $\mathrm{CD}^{+} \mathrm{CD} 8^{+}$ $\mathrm{T}$ cells' proliferation (Fig. 6k, Additional file 4: Figure S4I), suggesting that $\mathrm{CD} 2 \mathrm{v}$ can interfere with the proliferation of $\mathrm{T}$ cells in response to mitogens. However, the recombinant strain does not affect $\mathrm{CD}^{+}{ }^{+} \mathrm{T}$ cells' 


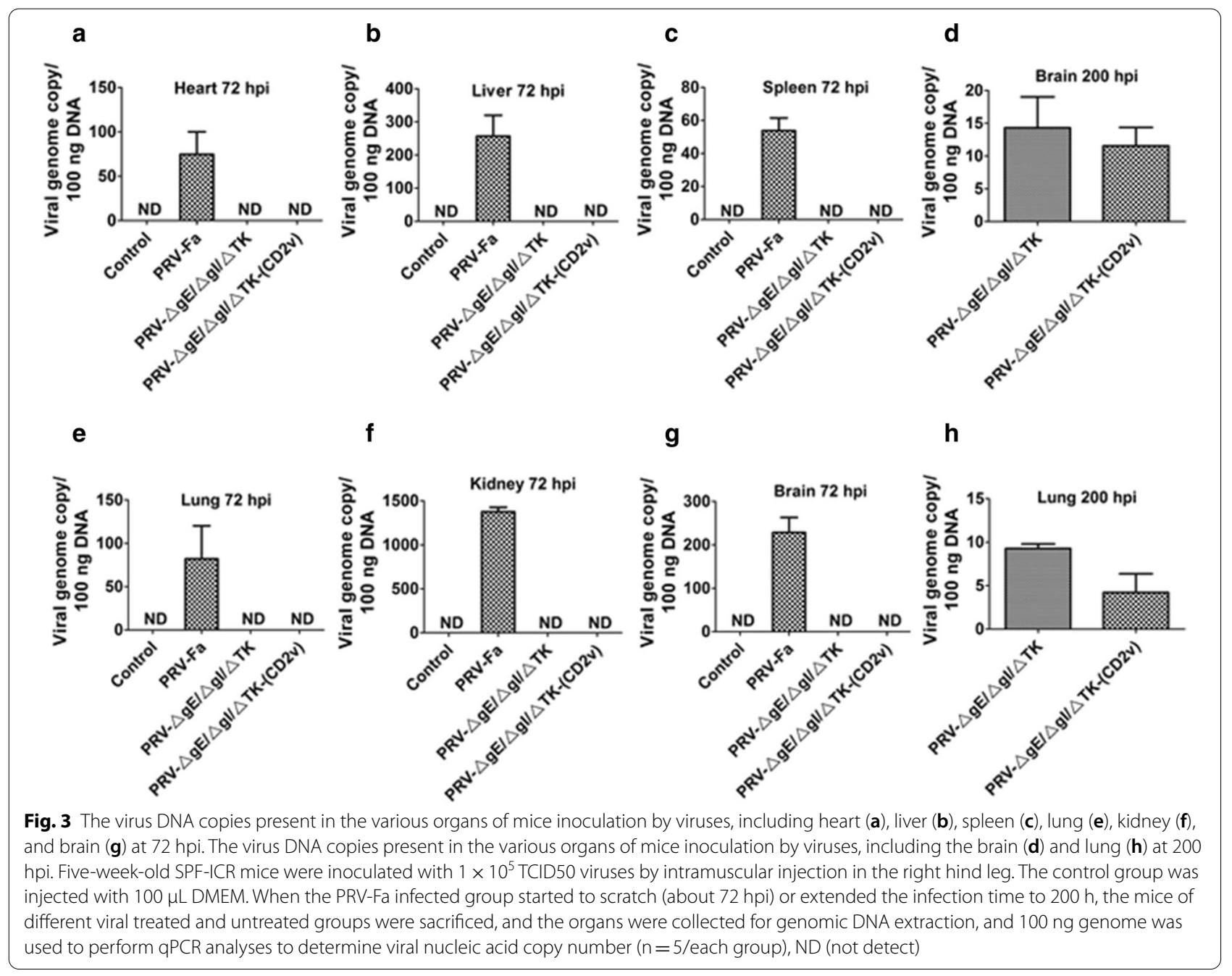

proliferation in the late stage of infection $(200 \mathrm{hpi})$ (Additional file 5: Figure S5D).

We also analyzed $T$ cells' activation after inoculation and found that PRV- $\Delta \mathrm{gE} / \Delta \mathrm{gI} / \Delta \mathrm{TK}$ did not activate $\mathrm{T}$ cells both recombinant and virulent strains can activate $\mathrm{CD}^{+}$and $\mathrm{CD}^{+}{ }^{+} \mathrm{T}$ cells at $72 \mathrm{hpi}$. Recombinant strains' ability to activate $\mathrm{T}$ cells was stronger than that of virulent strain (Fig. 7e, j, o). However, the activation of T cells by PRV $-\Delta \mathrm{gE} / \Delta \mathrm{gI} / \Delta \mathrm{TK}$ was detected in the late stage of infection (200 hpi), mainly manifested as the activation of $\mathrm{CD}^{+} \mathrm{T}$ cells (Additional file 5: Figure S5D, S5H and S5L). These data suggest that both PRV- $\Delta \mathrm{gE} / \Delta \mathrm{gI} / \Delta \mathrm{TK}$ and PRV- $\Delta \mathrm{gE} / \Delta \mathrm{gI} / \Delta \mathrm{TK}-(\mathrm{CD} 2 \mathrm{v})$ can stimulate the cellular immune response.

Because we made the fusion expression of $C D 2 v$ with Flag, the CD2v antibody production was indirectly estimated by anti-Flag reaction using ELISA. The immunization was conducted twice with an interval of 7 days. We only found the Flag antibody in PRV- $\Delta \mathrm{gE} / \Delta \mathrm{gI} /$
$\Delta \mathrm{TK}-(\mathrm{CD} 2 \mathrm{v})$-infected group (Fig. 8a), and the production of Flag antibody was increased after enhanced immunization. Besides, since IFNY is a major marker for T cell activation, we also measured the expression of IFN $\gamma$ induced by $C D 2 v$ in vitro. On the 7th day after the second immunization, mouse PBMCs were isolated and stimulated with purified (N-CD2v)-His (Additional file 6: Figure S6). We observed a significant increase in the IFNY mRNA expression in PBMCs (Fig. 8b). These data suggest that the PRV- $\Delta \mathrm{gE} / \Delta \mathrm{gI} / \Delta \mathrm{TK}-(\mathrm{CD} 2 \mathrm{v})$ is highly immunogenic and can induce specific cellular and humoral immune responses in mice.

\section{Recombinant strains can $100 \%$ protect mice from challenge by the virulent strain}

To investigate if the recombinant virus could induce protective immunity, the PRV-Fa was used to challenge the mice pretreated with PRV- $\Delta \mathrm{gE} / \Delta \mathrm{gI} / \Delta \mathrm{TK}$ or PRV- $\Delta \mathrm{gE} /$ $\Delta$ gI/ $\Delta$ TK-(CD2v). As shown in Fig. 8c, the control group 


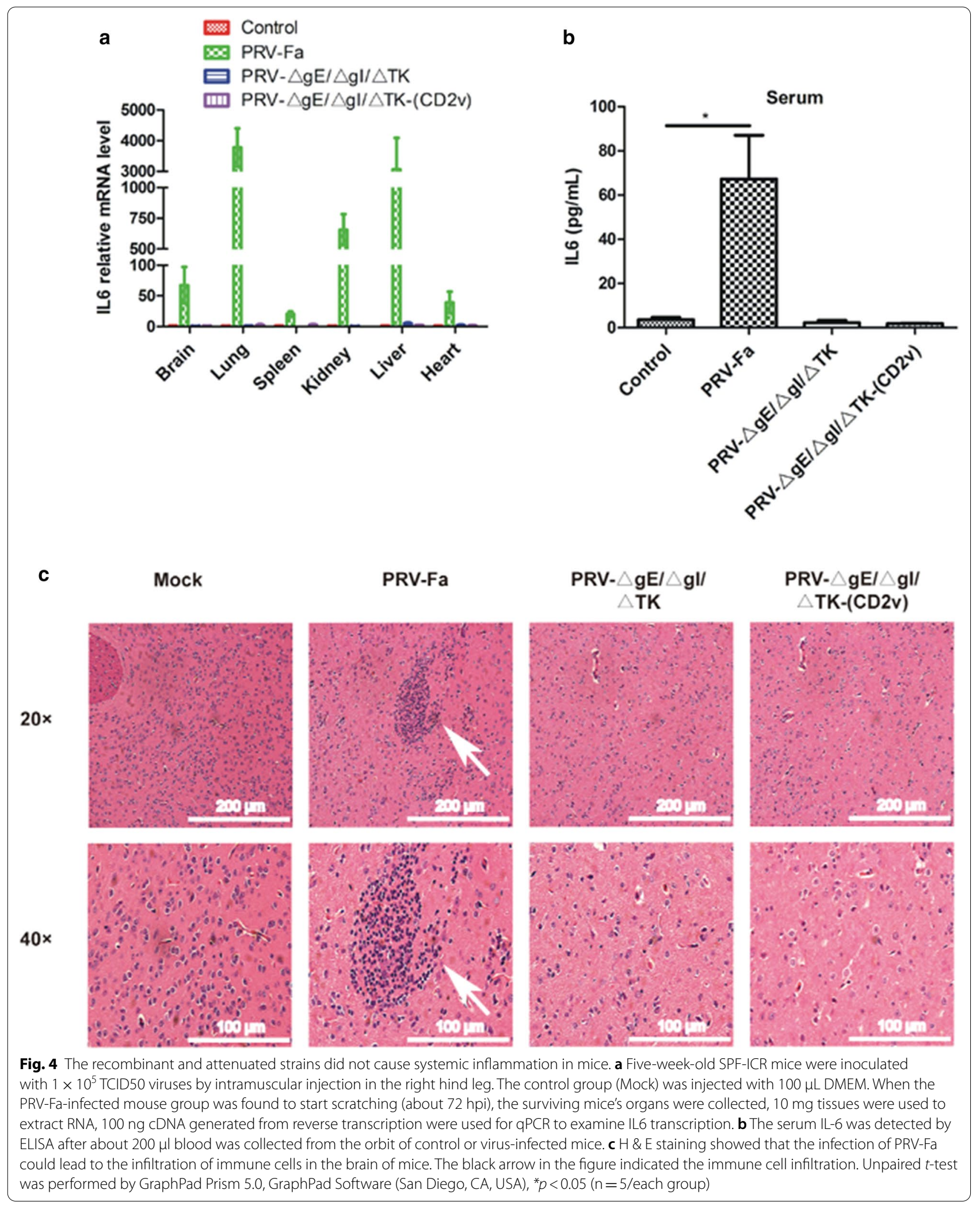


a
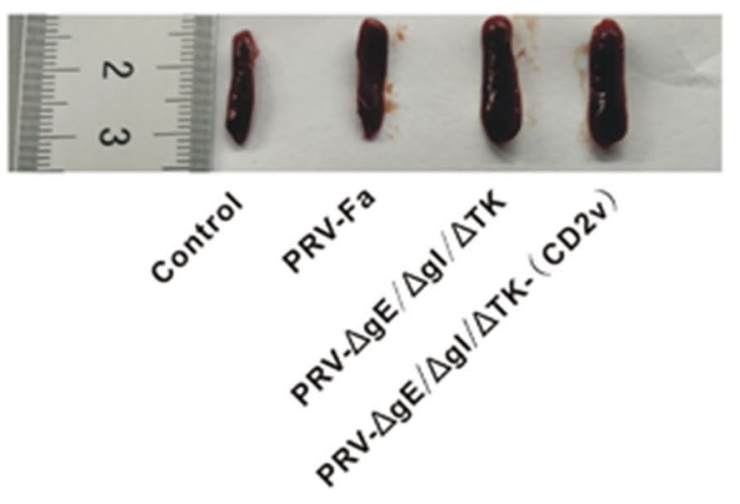

C

Control
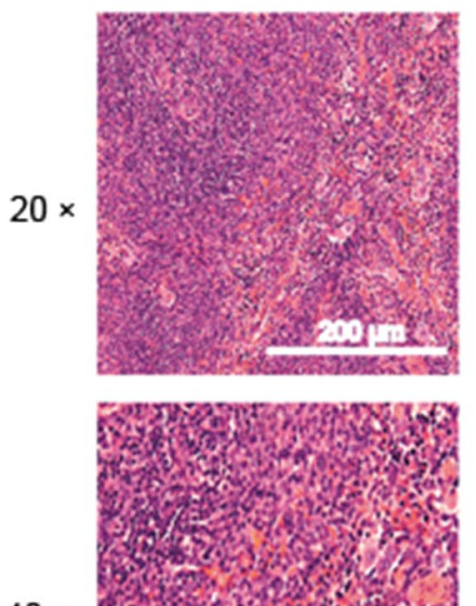

$40 \times$

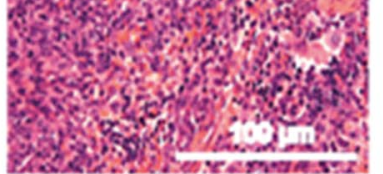

PRV-Fa
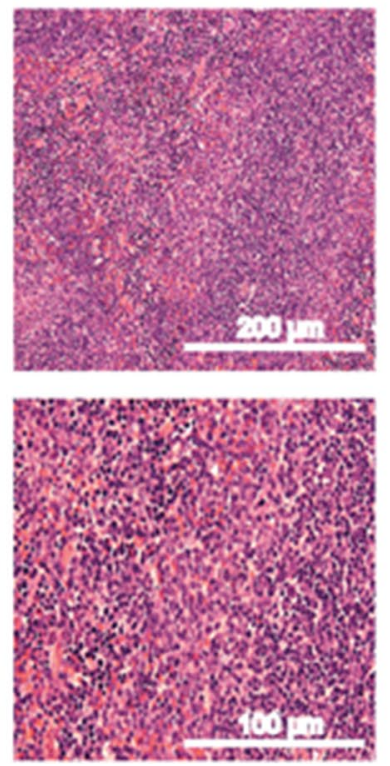

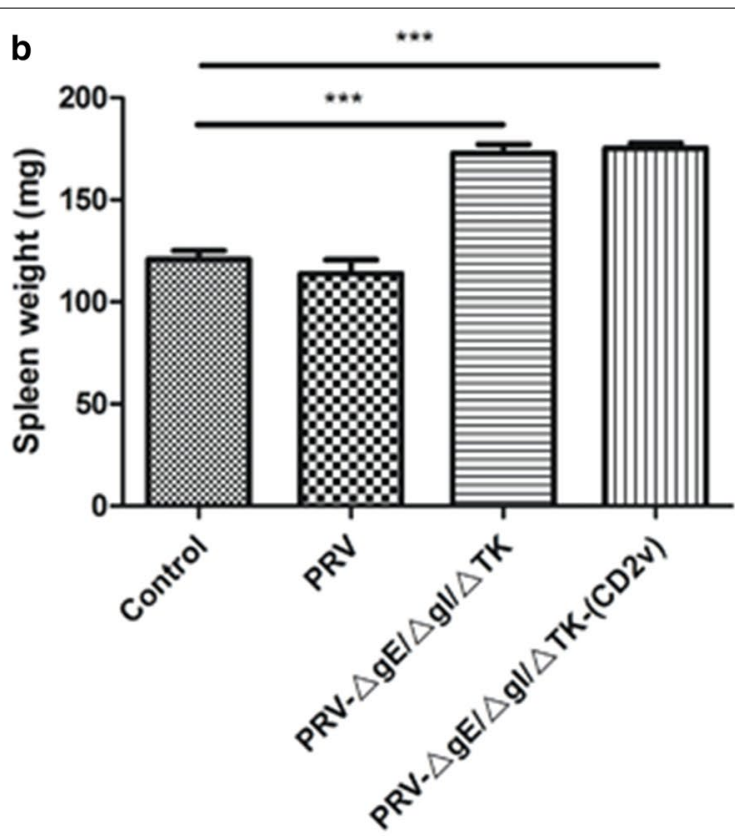

$\mathrm{PRV}-\triangle \mathrm{gE} / \triangle \mathrm{gl} / \triangle \mathrm{TK}$
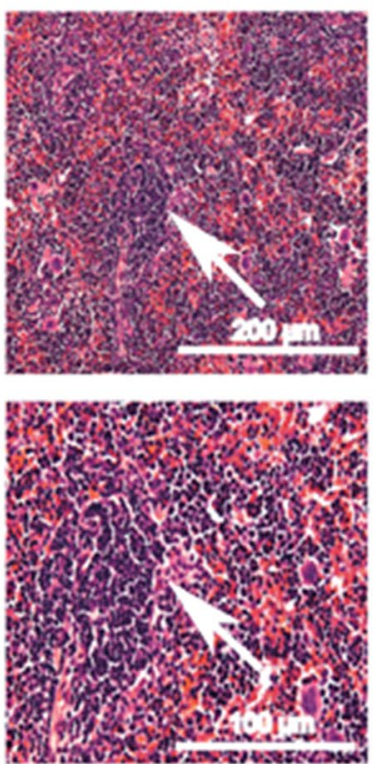

PRV- $\triangle \mathrm{gE} / \triangle \mathrm{gl} /$

$\triangle \mathrm{TK}-(\mathrm{CD} 2 \mathrm{v})$
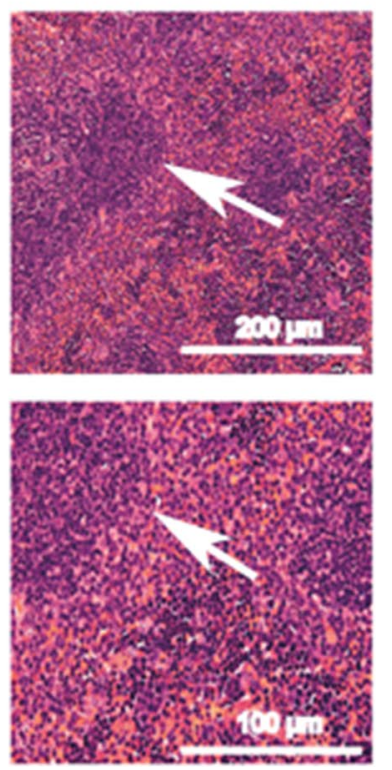

Fig. 5 Both PRV- $\triangle g E / \Delta g l / \Delta T K$ and PRV- $\triangle g E / \Delta g l / \Delta T K-(C D 2 v)$ can activate the immune responses and cause the proliferation of immune cells leading to splenomegaly. a The spleen of 72 hpi mice inoculated with PRV- $\Delta \mathrm{gE} / \Delta \mathrm{gl} / \Delta T \mathrm{TK}$ and PRV- $\Delta \mathrm{gE} / \Delta \mathrm{gl} / \Delta \mathrm{TK}$-(CD2v) was swollen obviously. $\mathbf{b}$ Spleen weight statistics. $\mathbf{c} H$ \& E staining showed that the spleen of PRV- $\Delta \mathrm{gE} / \Delta \mathrm{gl} / \Delta \mathrm{TK}$ and PRV- $\Delta \mathrm{gE} / \Delta \mathrm{gl} / \Delta \mathrm{TK}-(\mathrm{CD} 2 \mathrm{v})$ infected groups had a large number of immune cell accumulation, as shown by the black arrow. Unpaired $t$-test was performed by GraphPad Prism 5.0, GraphPad Software (San Diego, CA, USA), ${ }^{* * *} p<0.001$ ( $n=5$ /each group)

died on the 4th day of the PRV-Fa challenge, while both $\mathrm{PRV}-\Delta \mathrm{gE} / \Delta \mathrm{gI} / \Delta \mathrm{TK}$ and $\mathrm{PRV}-\Delta \mathrm{gE} / \Delta \mathrm{gI} / \Delta \mathrm{TK}-(\mathrm{CD} 2 \mathrm{v})$ immunized groups did not die until the 14th day. Meanwhile, we examined the detoxification effects in mice after the PRV-Fa challenge. The peak of detoxification in the control group lagged behind that in the immunized groups, a large amount of detoxification began on the second day of the PRV-Fa challenge in the immunized groups and the detoxification was not detected until the 4th day, while in the control group, a large amount 


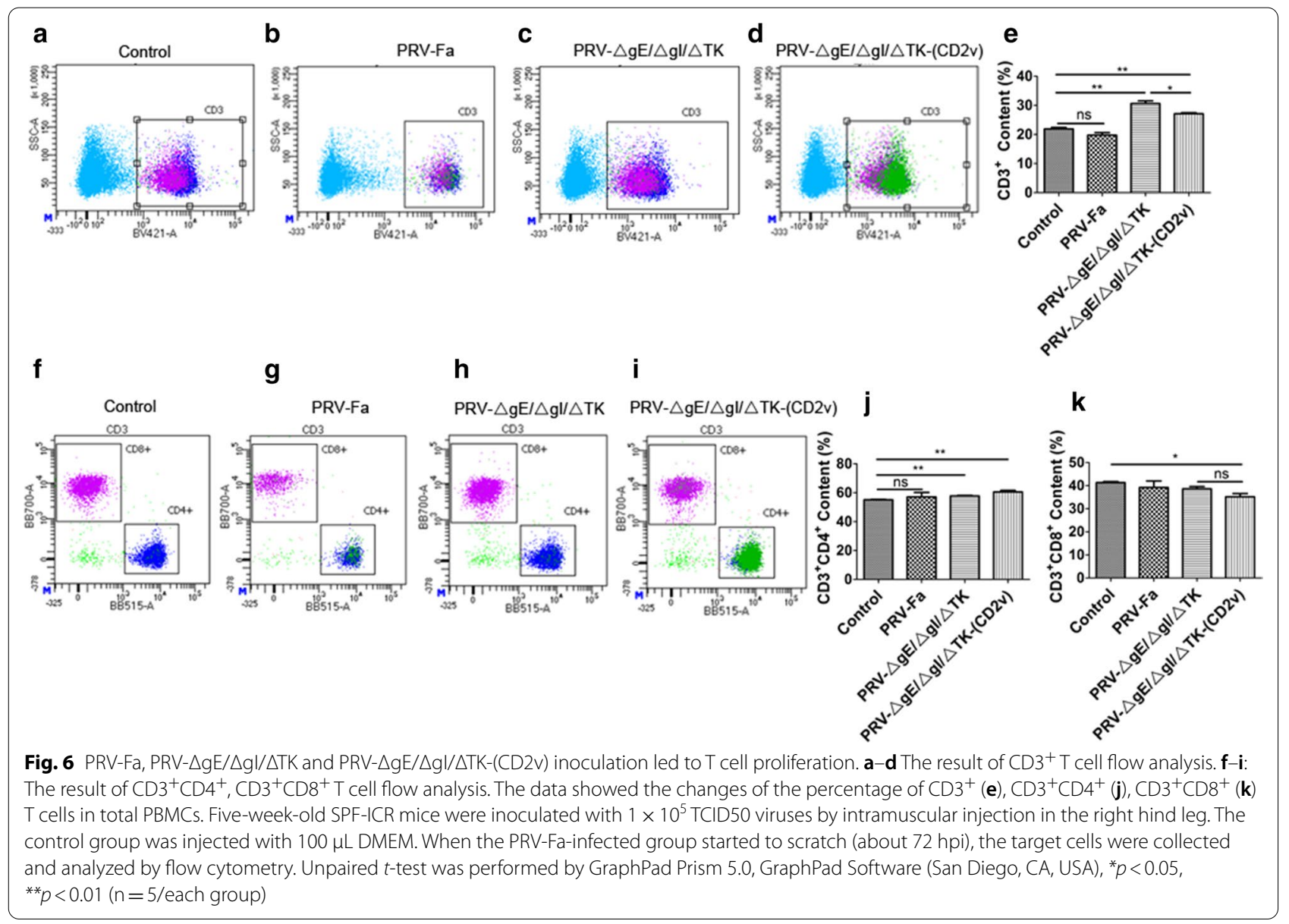

of detoxification was seen on the 3rd day after the PRVFa challenge (Fig. 8d), indicating that the virulent virus could not rapidly replicate in the mice immunized with PRV- $\Delta \mathrm{gE} / \Delta \mathrm{gI} / \Delta \mathrm{TK}$ or $\mathrm{PRV}-\Delta \mathrm{gE} / \Delta \mathrm{gI} / \Delta \mathrm{TK}-(\mathrm{CD} 2 \mathrm{v})$. Therefore, immunization with $\mathrm{PRV}-\Delta \mathrm{gE} / \Delta \mathrm{gI} / \Delta \mathrm{TK}$ or $\mathrm{PRV}-\Delta \mathrm{gE} / \Delta \mathrm{gI} / \Delta \mathrm{TK}-(\mathrm{CD} 2 \mathrm{v})$ can $100 \%$ protect the mice challenged by PRV-Fa.

\section{Discussion}

The outbreak of ASF has seriously threatened the development of the pig breeding industry, but there is no effective vaccine to prevent the disease. Various ASFV vaccines have been made, but none has been commercially used [14, 16, 20, 25]. Although some viral vector vaccines have good in vitro proliferation capacity, low production costs, and can effectively activate $\mathrm{T}$ cell immune responses [44], many other vaccines have suffered from low yields, high production costs, many side effects, and poor protection capabilities [7, 12, 23]. Pseudorabies virus is a good example of many replication nonessential genes such as gE, gI, TK and so on in its huge genome. While replaced by foreign genes, the virulent virus can become a safe and effective recombinant virus vector vaccine such as JS-2012- $\Delta$ gE/gI-E2, PRV SA215/ VP2, and PRV-P12A3C [39-41]. The alpha-herpes virus thymidine kinase (TK) gene is unnecessary for virus replication but is a gene related to virulence. It is usually the target gene of choice for constructing live attenuated vaccines with gene deletions and genetically engineered vector vaccines with foreign genes inserted and expressed.

The TK, gE, and gI three-gene deletion strain (PRV $\left.\mathrm{TK}^{-} / \mathrm{gE}^{-} / \mathrm{gI}^{-}(\mathrm{Fa})\right)$ has been developed and commercially used as a live attenuated vaccine in China. Compared with current epidemic PRV strains, its safety has been accepted [30]. Currently, the vaccines can target both genotype I and II strains, while type II is the prevalent strain in China. CD2v plays a major role in ASFV immune escape and tissue phagocytosis. As a key virulence gene, CD2v is usually deleted in the development of live attenuated vaccines [45]. Numerous studies have shown that $\mathrm{CD} 2 \mathrm{v}$ to provides partial protection as a subunit vaccine, DNA vaccine, and viral vector vaccine, indicating that $\mathrm{CD} 2 \mathrm{v}$ can induce immune protection [44]. In this study, we inserted the ASFV EP402R (CD2v) gene 


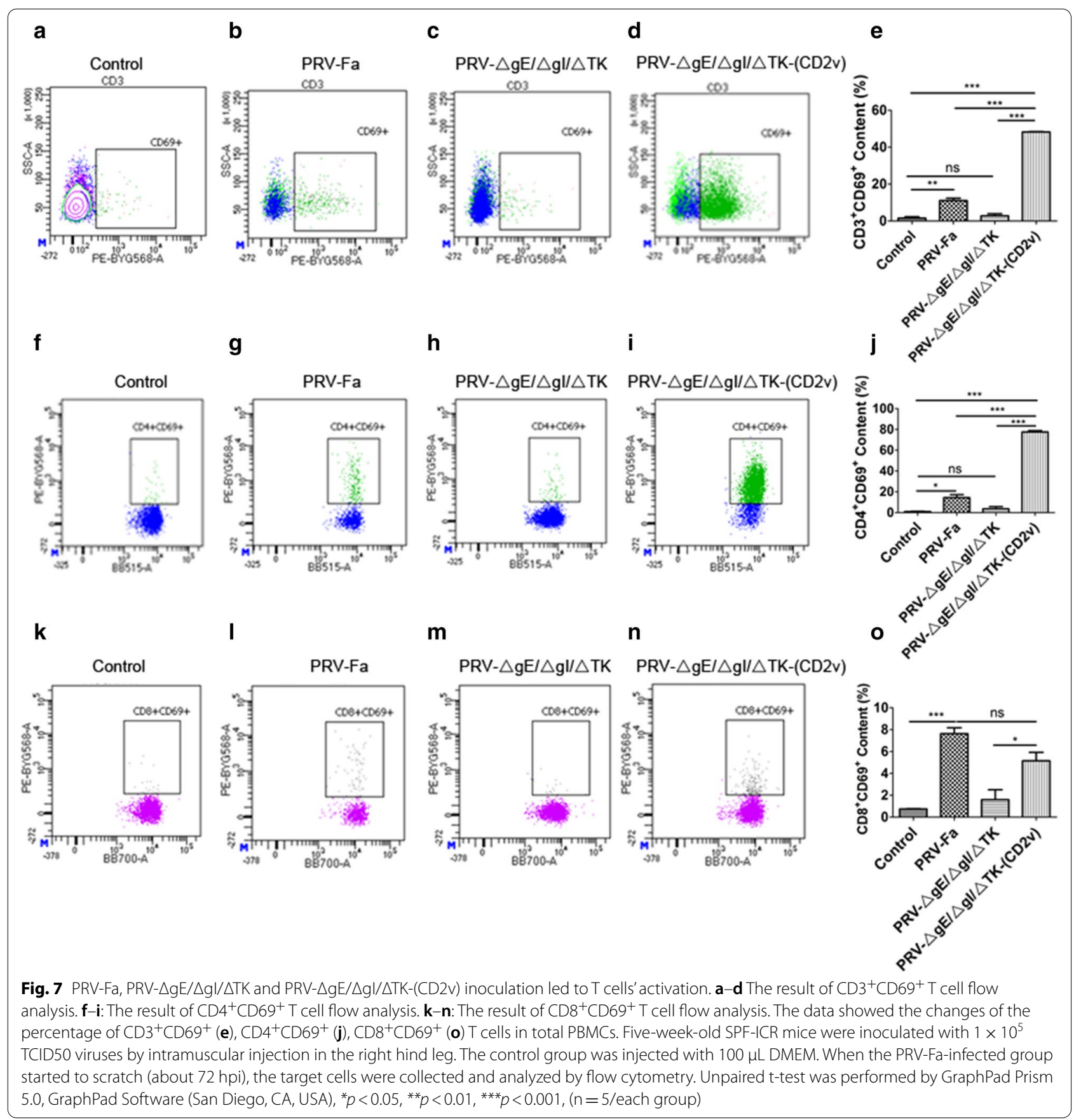

into the TK gene site of PRV- $\Delta \mathrm{gE} / \Delta \mathrm{gI}$ to generate PRV$\Delta \mathrm{gE} / \Delta \mathrm{gI} / \Delta \mathrm{TK}-(\mathrm{CD} 2 \mathrm{v})$ by the CRISPR/Cas9 technology [46-48]. This virus strain is quite stable since $C D 2 v$ is still expressed in infected Vero cells after 20 generations of passages. Previous studies suggest that CD2v processing is mainly depended on the infection of ASFV since the $\mathrm{CD} 2 \mathrm{v}$ protein is not processed in uninfected cells [42]. In contrast, we observed several $\mathrm{CD} 2 \mathrm{v}$ processed isoforms in pcDNA3.1-EGFP-Flag-CD2v-Flag plasmid transfected and PRV- $\Delta \mathrm{gE} / \Delta \mathrm{gI} / \Delta \mathrm{TK}-(\mathrm{CD} 2 \mathrm{v})$ infected HEK $293 \mathrm{~T}$ cells. Thereby, we suggest that the processing of $\mathrm{CD} 2 \mathrm{v}$ does not depend on the infection of ASFV, but may be related to cell types and cell death process.

CD2v is related to ASFV tissue phagocytosis [49]. To test whether the insertion of $C D 2 \mathrm{v}$ would change the tissue pathology of PRV- $\Delta \mathrm{gE} / \Delta \mathrm{gI} / \Delta \mathrm{TK}$, we examined the viral copy number of mouse organ tissues. We found virus nucleic acid only in the various tissues, including 
a œ $\mathrm{PRV}-\triangle \mathrm{gE} / \triangle \mathrm{gl} / \triangle \mathrm{TK}$ 曰PRV- $\triangle \mathrm{gE} / \triangle \mathrm{gl} / \triangle \mathrm{TK}-(\mathrm{CD} 2 \mathrm{v})$

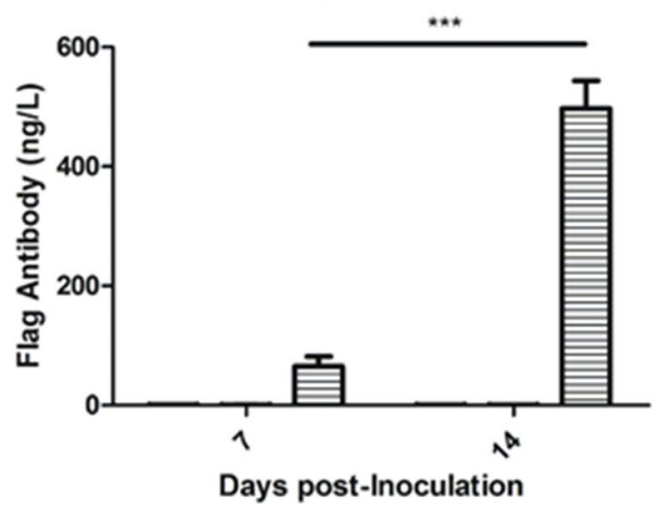

C
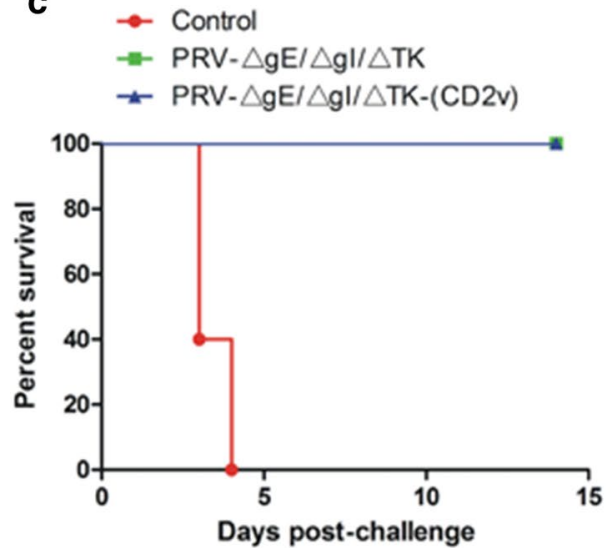

b

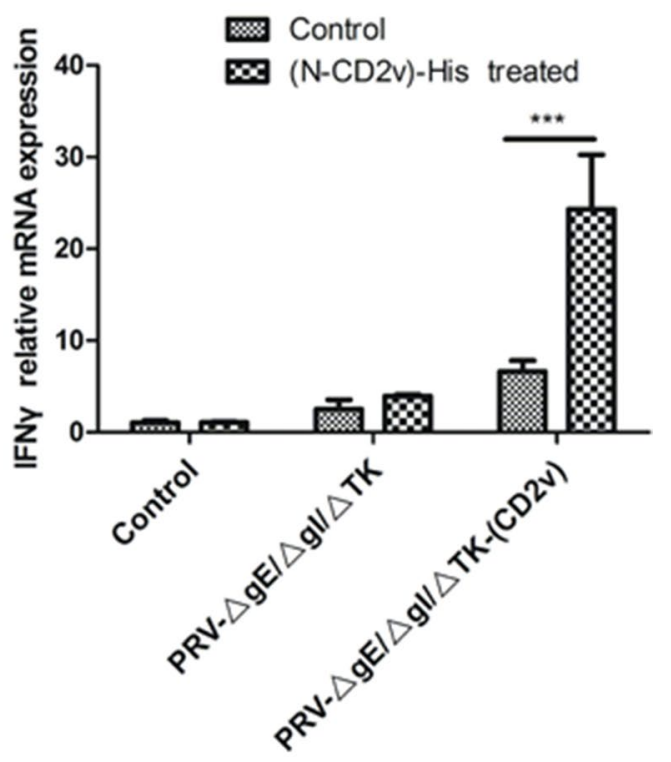

d
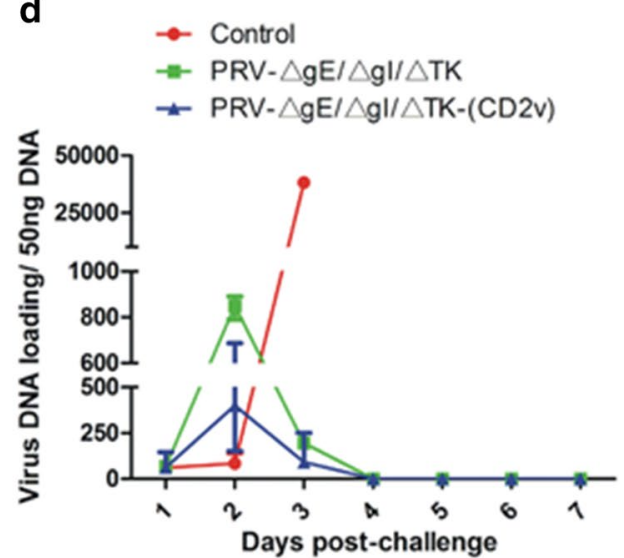

Fig. 8 After immunization, the recombinant attenuated virus can produce anti-CD2v specific antibody and specific cell response and has a 100\% protective effect against challenge by virulent strains. a Anti-CD2v specific antibody can be produced by immunizing the recombinant strain. Five-week-old SPF-ICR mice were immunized with $1 \times 10^{5} \mathrm{TCID} 50$ viruses by intramuscular injection in the right hind leg. The second immunization was carried out 7 days after the first immunization. The control group was injected with $100 \mu \mathrm{L}$ DMEM. About $200 \mu \mathrm{l}$ blood was collected from the orbit before and 7 days after each immunization for ELSIA to detect Flag antibody ( $n=5 /$ each group). $\mathbf{b}$ IFNy was detected at high transcription level when PBMC was stimulated with purified ( $\mathrm{N}-\mathrm{CD} 2 \mathrm{v}$ )-His ( $n=5$ /each group). c Recombinant strain can 100\% protect mice from virulent virus challenge. After the second immunization for 7 days, challenged with $5 \times 10^{5}$ TCID50 PRV-Fa, and the survival curve was drawn ( $n=15 /$ each group). $\mathbf{d}$ There was less detoxification in the recombinant attenuated virus-infected groups in response to the PRV-Fa challenge. After the PRV-Fa challenge, the feces of mice were collected every day to detect the number of virus copies ( $n=5 /$ each group). Two-way ANOVA was performed by GraphPad Prism 5.0, GraphPad Software (San Diego, CA, USA), ${ }^{* * *} p<0.001$

the brain of the mice infected with PRV-Fa, but not PRV$\Delta \mathrm{gE} / \Delta \mathrm{gI} / \Delta \mathrm{TK})$ or PRV- $\Delta \mathrm{gE} / \Delta \mathrm{gI} / \Delta \mathrm{TK}-(\mathrm{CD} 2 \mathrm{v})$ at $72 \mathrm{hpi}$. Extending the infection time to $200 \mathrm{~h}$, we detected viral nucleic acids in the brain and lung tissues of mice in the PRV- $\Delta \mathrm{gE} / \Delta \mathrm{gI} / \Delta \mathrm{TK}$ group or PRV- $\Delta \mathrm{gE} / \Delta \mathrm{gI} / \Delta \mathrm{TK}-(\mathrm{CD} 2 \mathrm{v})$ group. But unlike PRV-Bartha, after prolonging the infection time, the viral load in the mouse brain is not higher than that of the virulent strain [32], suggesting that the virulence of the recombinant strain is weaker than PRVBartha. Unlike PRV-Fa, the infection with PRV- $\Delta \mathrm{gE} / \Delta \mathrm{gI} /$ $\Delta \mathrm{TK}$ and PRV- $\Delta \mathrm{gE} / \Delta \mathrm{gI} / \Delta \mathrm{TK}-(\mathrm{CD} 2 \mathrm{v})$ in mice did not cause pruritus and death. Systemic inflammation, especially neuroinflammation caused by virulent strains is the major cause of death in mice. IL6 is a major sign of 
systemic inflammation which can be induced by virulent virus infection such as PRV-Becker infection [32]. But, $\mathrm{PRV}-\Delta \mathrm{gE} / \Delta \mathrm{gI} / \Delta \mathrm{TK}$ or PRV- $\Delta \mathrm{gE} / \Delta \mathrm{gI} / \Delta \mathrm{TK}-(\mathrm{CD} 2 \mathrm{v})$ did not cause an IL6 increase in infected mice's tissues and sera. Besides, H\&E staining showed that only the PRV-Fa strain could cause brain inflammation in mice. Therefore, the insertion of $C D 2 \mathrm{v}$ does not change the virulence and tissue phagocytosis of the attenuated strain (PRV- $\Delta \mathrm{gE} /$ $\Delta \mathrm{gI} / \Delta \mathrm{TK})$, and the recombinant strain is safe for mice.

$\mathrm{CD} 2 \mathrm{v}$ is a decisive factor for ASFV infection of peripheral blood lymphocytes in vitro to inhibit lymphocyte proliferation in response to mitogens [43]. Whether $\mathrm{CD} 2 \mathrm{v}$ will inhibit $\mathrm{T}$ cell proliferation in vivo is still unknown. When we extracted the mouse organs, we found the splenomegaly in the mice inoculated with PRV$\Delta \mathrm{gE} / \Delta \mathrm{gI} / \Delta \mathrm{TK}$ or PRV- $\Delta \mathrm{gE} / \Delta \mathrm{gI} / \Delta \mathrm{TK}-(\mathrm{CD} 2 \mathrm{v})$, suggesting that the immunization of the attenuated strains activate the mouse immune system leading to the splenomegaly. We found that the spleen congestion filled with a large number of lymphocytes, and the inoculation of these attenuated strains increase $\mathrm{CD} 3^{+}, \mathrm{CD}^{+} \mathrm{CD}^{+}{ }^{+} \mathrm{T}$ cells. However, the ability of PRV- $\Delta \mathrm{gE} / \Delta \mathrm{gI} / \Delta \mathrm{TK}-(\mathrm{CD} 2 \mathrm{v})$ to induce $\mathrm{T}$ cell proliferation is weaker than PRV- $\Delta \mathrm{gE} / \Delta \mathrm{gI} /$ $\Delta \mathrm{TK}$, which is mainly manifested as inhibition of $\mathrm{CD}^{+}$ $\mathrm{T}$ cells, suggesting that $\mathrm{CD} 2 \mathrm{v}$ in the recombinant strain can still interfere with the proliferation of $\mathrm{T}$ cells in vivo, but with less capability. The structure and function of ASFV CD2v protein resemble that of the host CD2 [45]. $\mathrm{CD} 2$ can activate $\mathrm{T}$ cells after binding to its ligands [50]. Whether CD2v can activate T cells in vivo has not been reported previously. $\mathrm{CD} 69^{+}$cells are a major indicator of $\mathrm{T}$ cell activation [51]. We analyzed the $\mathrm{T}$ cell subtype and found that the recombinant strain can activate $\mathrm{T}$ cells after immunization; both $\mathrm{CD}^{+}$and $\mathrm{CD}^{+} \mathrm{T}$ cells are activated, but PRV- $\Delta \mathrm{gE} / \Delta \mathrm{gI} / \Delta \mathrm{TK}$ cannot activate $\mathrm{T}$ cells at $72 \mathrm{hpi}$. PRV $-\Delta \mathrm{gE} / \Delta \mathrm{gI} / \Delta \mathrm{TK}$ can also activate $\mathrm{T}$ cells, but this occurs at the late stage $(200 \mathrm{hpi})$ of infection. These data suggest that $\mathrm{CD} 2 \mathrm{v}$ can activate $\mathrm{T}$ cells in vivo. $\mathrm{CD}^{+}$delayed-type hypersensitivity-like effector cells are a crucial effector mechanism for protective immunity against PRV [52]. Compared with PRV- $\Delta \mathrm{gE} / \Delta \mathrm{gI} / \Delta \mathrm{TK}$, the recombinant strain can activate more $\mathrm{CD} 4^{+} \mathrm{T}$ cells. Therefore, the recombinant strain is more suitable for the prevention of pseudorabies.

Adenovirus, vaccinia virus Ankara and alphavirus are often used to develop ASFV virus vector vaccines. They can induce specific antibody production or $\mathrm{T}$ cell immune response, but most of their protection capabilities have not been verified [5]. In this study, the production of the specific antibody targeting CD2v has also been manifested by the indirect examination of the antiFlag antibody production since $C D 2 v$ is fused with the Flag-tag and the detection of the anti-Flag antibody can represent the expression antigenicity of $\mathrm{CD} 2 \mathrm{v}$ protein. But, we can not exclude the other possibilities that may interfere with the $C D 2 v$ expression or the inability of antibody production associated with $\mathrm{CD} 2 \mathrm{v}$ production, processing, or antigen-presenting, so on. It has shown that $\mathrm{CD} 2 \mathrm{v}$ protein can protect piglets from the ASFV challenge, even the neutralizing antibody is not present, which implicates the other factors that may be involved in counteracting the viral infection [15]. Previous studies have shown that pigs with depleted $\mathrm{CD} 8^{+} \mathrm{T}$ cells are not immune protected and suggested that a vaccine that can stimulate T-cell-mediated response may also reserve its ability to protect against ASFV infection $[19,53]$.

Interestingly, our data show that PRV- $\Delta \mathrm{gE} / \Delta \mathrm{gI} / \Delta \mathrm{TK}-$ $(\mathrm{CD} 2 \mathrm{v})$ can effectively activate the immune system to produce specific antibodies with strong immunogenicity. Besides, purified $\mathrm{CD} 2 \mathrm{v}$ protein can also induce IFNY expression, IFN $\gamma$ is a major marker for $\mathrm{T}$ cell activation. Therefore, the PRV- $\Delta \mathrm{gE} / \Delta \mathrm{gI} / \Delta \mathrm{TK}-(\mathrm{CD} 2 \mathrm{v})$ strain can effectively activate specific $\mathrm{T}$ cell immune responses.

\section{Conclusions}

In summary, we constructed a PRV attenuated strain expressing ASFV CD2v protein (PRV- $\Delta \mathrm{gE} / \Delta \mathrm{gI} / \Delta \mathrm{TK}$ (CD2v)) by the CRISPR/Cas9 technology. The recombinant strain showed good safety and immunogenicity in mice. When facing a virulent virus challenge, it has $100 \%$ protective ability and can induce $C D 2 v$ specific humoral and cellular immune responses in mice. Therefore, it may be used as a recombinant vaccine candidate to prevent ASF and Pseudorabies, but further studies are needed to confirm the effectiveness of this attenuated strain in pigs.

\section{Supplementary information}

Supplementary information accompanies this paper at https://doi. org/10.1186/s12985-020-01450-7.

Additional file 1. Figure S1: The infection of a virulent strain caused severe itching in mice. Five-week-old SPF-ICR mice were inoculated with 1 $\times 10^{5} \mathrm{TCID} 50$ viruses by intramuscular injection in the right hind leg. The control group (Mock) was injected with $100 \mu \mathrm{L}$ DMEM. The itching symptom appeared in the group inoculated with the virulent strain at about 72 hpi, and the red coil area was the scratched and bitten area of the mouse.

Additional file 2. Figure S2: qPCR analyses of viral nucleic acid copies, the detection of viral nucleic acid limit was between 10 and 100 copies. A: pCDH-UL42 plasmid map. B: Standard curve amplification curve, the plasmid of pCDH-UL42 with $1 \mathrm{ng}, 0.1 \mathrm{ng}, 0.01 \mathrm{ng}, 0.001 \mathrm{ng}, 0.0001 \mathrm{ng}, 0.00001$ ng, $0.00001 \mathrm{ng}, 0.000001 \mathrm{ng}$ was used for the qPCR reaction. C: Standard curve equation was drawn, the CT value was shown at the horizontal axis, while the vertical axis represented the Log10 plasmid copy number. D: Gel electrophoresis of qPCR products.

Additional file 3. Figure S3: PRV- $\triangle g E / \triangle g l / \triangle T K$ or PRV- $\triangle g E / \triangle g l / \triangle T K$ (CD2v) infection showed no difference in spleen weight than the control group (200 hpi). Five-week-old SPF-ICR mice were inoculated with $1 \times 10^{5}$ TCID50 viruses by intramuscular injection in the right hind leg. The control group was injected with $100 \mu \mathrm{L}$ DMEM. Spleen was collected for weighing 
at 200 hpi. Unpaired t-test was performed by GraphPad Prism 5.0, GraphPad Software (San Diego, CA, USA), ns (not significant).

Additional file 4. Figure S4: PRV- $\triangle g E / \Delta g I / \Delta T K$ and PRV- $\triangle g E / \Delta g I / \Delta T K$ (CD2v) inoculation led to T cell proliferation at $200 \mathrm{hpi}$. A-C: The results of $\mathrm{CD}^{+} \mathrm{T}$ cell flow analyses. E-G: The results of $\mathrm{CD}^{+} \mathrm{CD}^{+}, \mathrm{CD}^{+}{ }^{+} \mathrm{CD} 8^{+} \mathrm{T}$ cell flow analyses. The data showed the changes of the percentage of $\mathrm{CD}^{+}$ (D), $\mathrm{CD}^{+} \mathrm{CD}^{+}(\mathrm{H}), \mathrm{CD}^{+} \mathrm{CD}^{+}$(I) T cells in total PBMCs. Five-week-old SPF-ICR mice were inoculated with $1 \times 10^{5} \mathrm{TCID} 50$ viruses by intramusCular injection in the right hind leg. The control group was injected with 100 $\mu \mathrm{L}$ DMEM. The target cells were collected and analyzed by flow cytometry after $200 \mathrm{~h}$ of virus infection. Unpaired t-test was performed by GraphPad Prism 5.0, GraphPad Software (San Diego, CA, USA), ${ }^{*} p<0.05$ ( $n=5$ /each group).

Additional file 5. Figure S5: PRV- $\triangle g E / \Delta g l / \Delta T K$ and PRV- $\triangle g E / \Delta g l / \Delta T K-$ (CD2v) inoculation led to T cells' activation at $200 \mathrm{hpi}$. A-C: The result of $\mathrm{CD}^{+}{ }^{+} \mathrm{CD} 69^{+} \mathrm{T}$ cell flow analysis. E-G: The result of $\mathrm{CD} 4^{+} \mathrm{CD} 69^{+} \mathrm{T}$ cell flow analysis. I-K: The result of $\mathrm{CD} 8^{+} \mathrm{CD} 69^{+} \mathrm{T}$ cell flow analysis. The data showed the changes of the percentage of $\mathrm{CD}_{3}{ }^{+} \mathrm{CD} 69^{+}(\mathrm{D}), \mathrm{CD}_{4}{ }^{+} \mathrm{CD} 69^{+}$ $(\mathrm{H}), \mathrm{CD}^{+}{ }^{+} \mathrm{CD} 69^{+}(\mathrm{L}) \mathrm{T}$ cells in total PBMCs. Five-week-old SPF-ICR mice were inoculated with $1 \times 10^{5} \mathrm{TCID} 50$ viruses by intramuscular injection in the right hind leg. The control group was injected with $100 \mu \mathrm{L}$ DMEM. The target cells were collected and analyzed by flow cytometry after 200 h of virus infection. Unpaired t-test was performed by GraphPad Prism 5.0, GraphPad Software (San Diego, CA, USA), ${ }^{*} p<0.05,{ }^{* *} p<0.01,{ }^{* * *} p<$ 0.001 , $(n=5 /$ each group).

Additional file 6. Figure S6: Purification of (N-CD2v)-His recombinant protein. Coomassie brilliant blue staining results, lanes 1 and 7 are markers, lane 2 is the supernatant of EXPi 293 cell lysate transfected with pcDNA3.4 empty vector, lane 3 is EXPi 293 cell transfected with pcDNA3.4-(N-CD2v)-His the supernatant of EXPi 293 cell lysate, lane 4 is the penetrating solution of the transfected pcDNA3.4-(N-CD2v)-His EXPi 293 cell lysate after passing through the nickel column, and lane 5 is the Wash buffer after washing nickel column liquid permeation, lane 6 is the sample eluent collected by the Elution buffer.

\section{Abbreviations}

ASF: African swine fever; ASFV: African swine fever virus; PRV: Pseudorabies virus; CPE: Cytopathic effects; DMEM: Dulbecco's modified Eagle's Medium; ELISA: Enzyme-linked immunosorbent assay; CTL: Cytotoxic T lymphocyte; HEK: Human embryonic kidney; FBS: Fetal bovine serum; FITC: Fluorescein isothiocyanate; mAb: Monoclonal antibody; H\&E staining: HematoxylinEosin Staining; PBS: Phosphate buffered saline; IgG: Immunoglobulin G; KD: Thousand Daltons; PBMC: Peripheral blood lymphocytes; hpi: Hour postinfection; KO: Knockout; PCR: Polymerase chain reaction; IL6: Interleukin-6; IFN- $\gamma$ : Interferon- $\gamma$; TNF-a: Tumor necrosis factor- $\alpha$; IL1 $\beta$ : Interleukin 1- $\beta$; IFN $\beta$ : Interferon- $\beta$; qPCR: Quantitative polymerase chain reaction; qRT-PCR: Quantitative reverse transcription-polymerase chain reaction; SEM: Standard error of the mean; TCID50: Tissue culture infective dose; MUS: Mouse; F: Forward; R: Reverse.

\section{Acknowledgements}

We would like to thank Yajuan Fu and Zhang Lin for administrative assistance and the members of Chen's laboratory for technical assistance and helpful discussion.

\section{Authors' contributions}

Qi Chen, Zhihua Feng, Zhaolong Li, and Shaoli Cai conceived the experiments. Zhihua Feng, Shaoli Cai, Zhaolong Li, and Qi Chen wrote the manuscript. Zhihua Feng, Jianghua Chen, Wangwang Liang, and Wenzhi Chen performed the main experiments. Zhihua Feng and Jianghua Chen statistically analyzed all data. All authors read and approved the final manuscript.

\section{Funding}

Natural Science Foundation of the Fujian Province, China (Grant No. 2017J01621), Fujian Key Laboratory of Innate Immune Biology (Grant No. 2015J1001), Fujian Public Welfare Fund (Grant No. 2018R1023-15).

\section{Availability of data and materials}

The data used to support the findings of this study are included in this published article.

\section{Ethics approval and consent to participate}

The animal experiments were performed under the Guide for the Care and Use of Laboratory Animals approved by Fujian Provincial Office for Managing Laboratory Animals and were overseen by the Fujian Normal University Animal Care and Use Committee (SYXK: 2015-0004).

\section{Consent for publication}

Not applicable.

\section{Competing interests}

The authors declare no competing interests.

\section{Author details}

${ }^{1}$ Fujian Key Laboratory of Innate Immune Biology, Biomedical Research Center of South China, Fujian Province, Fujian Normal University Qishan Campus, College Town, Fuzhou 350117, People's Republic of China. ${ }^{2}$ Institute of Animal Husbandry and Veterinary Medicine, Fujian Province, Fujian Academy of Agricultural Sciences, Pudang, Jin-an District, Fuzhou 350117, People's Republic of China.

Received: 8 July 2020 Accepted: 5 November 2020

Published online: 16 November 2020

\section{References}

1. Zhao D, Liu R, Zhang X, Li F, Wang J, Zhang J, Liu X, Wang L, Zhang J, Wu $X$. Replication and virulence in pigs of the first African swine fever virus isolated in China. Emerg Microbes Infect. 2019;8:438-47.

2. Wang $N$, Zhao D, Wang JB, Zhang Y, Wang M, Gao Y, Li F, Wang J, Bu Z, Rao Z. Architecture of African swine fever virus and implications for viral assembly. Science. 2019;366:640-4.

3. Gallardo C, Nurmoja I, Soler A, Delicado V, Simon A, Martin E, Perez C, Nieto R, Arias M. Evolution in Europe of African swine fever genotype II viruses from highly to moderately virulent. Vet Microbiol. 2018;219:70-9.

4. Ge S, Li J, Fan X, Liu F, Li L, Wang Q, Ren W, Bao J, Liu C, Wang H. Molecular characterization of African swine fever virus, China, 2018. Emerg Infect Dis. 2018:24:2131-3.

5. Gaudreault NN, Richt JA. Subunit vaccine approaches for African swine fever virus. Vaccine. 2019;7:56.

6. Dixon LK, Chapman DAG, Netherton CL, Upton C. African swine fever virus replication and genomics. Virus Res. 2013;173:3-14.

7. De Villiers EP, Gallardo C, Arias M, Silva MD, Upton C, Martin R, Bishop RP. Phylogenomic analysis of 11 complete African swine fever virus genome sequences. Virology. 2010;400:128-36.

8. Portugal R, Coelho J, Hoper D, Little NS, Smithson C, Upton C, Martins C, Leitao A, Keil GM. Related strains of African swine fever virus with different virulence: genome comparison and analysis. J Gen Virol. 2015;96:408-19.

9. Freitas FB, Frouco G, Martins C, Ferreira F. African swine fever virus encodes for an E2-ubiquitin conjugating enzyme that is mono- and di-ubiquitinated and required for viral replication cycle. Sci Rep . 2018:8:3471-3471.

10. Malogolovkin A, Burmakina G, Titov IA, Sereda AD, Gogin A, Baryshnikova E, Kolbasov DV. Comparative analysis of African swine fever virus genotypes and serogroups. Emerg Infect Dis. 2015;21:312-5.

11. Farlow J, Donduashvili M, Kokhreidze M, Kotorashvili A, Vepkhvadze N, Kotaria N, Gulbani A. Intra-epidemic genome variation in highly pathogenic African swine fever virus (ASFV) from the country of Georgia. Virol J. 2018;15:190.

12. Kleiboeker SB, Scoles GA, Burrage TG, Sur J. African swine fever virus replication in the midgut epithelium is required for infection of ornithodorosticks. J Virol. 1999;73:8587-98.

13. Forman AJ, Wardley RC, Wilkinson PJ. The immunological response of pigs and Guinea pigs to antigens of African swine fever virus. Adv Virol. 1982;74:91-100. 
14. Blome S, Gabriel C, Beer M. Modern adjuvants do not enhance the efficacy of an inactivated African swine fever virus vaccine preparation. Vaccine. 2014;32:3879-82.

15. Ruizgonzalvo F, Rodriguez F, Escribano JM. Functional and immunological properties of the baculovirus-expressed hemagglutinin of African Swine fever virus. Virology. 1996;218:285-9.

16. Gomezpuertas P, Rodriguez F, Oviedo JM, Brun A, Alonso C, Escribano JM. The African swine fever virus proteins p54 and p30 are involved in two distinct steps of virus attachment and both contribute to the antibodymediated protective immune response. Virology. 1998;243:461-71.

17. Lokhandwala S, Waghela SD, Bray J, Martin CL, Sangewar N, Charendoff C, Shetti R, Ashley C, Chen C, Berghman L. Induction of robust immune responses in swine by using a cocktail of adenovirus-vectored African swine fever virus antigens. Clin Vaccine Immunol. 2016;23:888-900.

18. Loperamadrid J, Osorio JE, He Y, Xiang Z, Adams LG, Laughlin RC, Mwangi W, Subramanya S, Neilan JG, Brake D. Safety and immunogenicity of mammalian cell derived and Modified Vaccinia Ankara vectored African swine fever subunit antigens in swine. Vet Immunol Immunopathol. 2017;185:20-33.

19. Oura CAL, Denyer MS, Takamatsu H, Parkhouse RME. In vivo depletion of CD8+ T lymphocytes abrogates protective immunity to African swine fever virus. J Gen Virol. 2005;86:2445-50.

20. Argilaguet J, Perezmartin E, Nofrarias M, Gallardo C, Accensi F, Lacasta A, Mora M, Ballester M, Galindocardiel I, Lopezsoria S. DNA vaccination partially protects against African swine fever virus lethal challenge in the absence of antibodies. PLOS ONE 2012,7.

21. Argilaguet J, Perezmartin E, Gallardo C, Salguero FJ, Borrego B, Lacasta A Accensi F, Diaz I, Nofrarias M, Pujols J. Enhancing DNA immunization by targeting ASFV antigens to SLA-II bearing cells. Vaccine. 2011;29:5379-85.

22. Lacasta A, Ballester M, Monteagudo PL, Rodriguez JM, Salas ML, Accensi F, Pinapedrero S, Bensaid A, Argilaguet J, Lopezsoria S. Expression library immunization can confer protection against lethal challenge with african swine fever virus. J Virol. 2014;88:13322-32.

23. King K, Chapman D, Argilaguet J, Fishbourne E, Hutet E, Cariolet R, Hutchings G, Oura CAL, Netherton CL, Moffat K. Protection of European domestic pigs from virulent African isolates of African swine fever virus by experimental immunisation. Vaccine. 2011;29:4593-600.

24. Boinas F, Hutchings GH, Dixon LK, Wilkinson PJ. Characterization of pathogenic and non-pathogenic African swine fever virus isolates from Ornithodoros erraticus inhabiting pig premises in Portugal. J Gen Virol. 2004;85:2177-87.

25. Odonnell V, Holinka LG, Gladue DP, Sanford BJ, Krug PW, Lu X, Arzt J, Reese $B$, Carrillo C, Risatti GR. African swine fever virus georgia isolate harboring deletions of MGF360 and MGF505 genes is attenuated in swine and confers protection against challenge with virulent parental virus. J Virol. 2015;89:6048-56

26. Gallardo C, Sanchez EG, Pereznunez D, Nogal M, De Leon P, Carrascosa AL, Nieto R, Soler A, Arias ML, Revilla Y. African swine fever virus (ASFV) protection mediated by NH/P68 and NH/P68 recombinant live-attenuated viruses. Vaccine. 2018;36:2694-704.

27. Sanchez EG, Quintas A, Pereznunez D, Nogal M, Barroso S, Carrascosa AL, Revilla Y. African swine fever virus uses macropinocytosis to enter host cells. PLOS Pathogens 2012,8.

28. Sanchez EG, Pereznunez D, Revilla Y. Mechanisms of entry and endosomal pathway of African Swine fever virus. Vaccine. 2017:5:42

29. Tong W, Li G, Liang C, Liu F, Tian Q, Cao Y, Li L, Zheng X, Zheng H, Tong G. A live, attenuated pseudorabies virus strain JS-2012 deleted for gE/ gl protects against both classical and emerging strains. Antiviral Res. 2016;130:110-7.

30. Ye C, Zhang Q, Tian Z, Zheng H, Zhao K, Liu F, Guo J, Tong W, Jiang C, Wang S. Genomic characterization of emergent pseudorabies virus in China reveals marked sequence divergence: Evidence for the existence of two major genotypes. Virology. 2015;483:32-43.

31. Verpoest S, Cay B, Favoreel H, De Regge N. Age dependent differences in pseudorabies virus neuropathogenesis and associated cytokine expression. J Virol. 2017, 91.

32. Laval K, Vernejoul JB, Van Cleemput J, Koyuncu OO, Enquist LW. Virulent pseudorabies virus infection induces a specific and lethal systemic inflammatory response in mice. J Virol. 2018, 92.

33. An T, Peng J, Tian Z, Zhao H, Li N, Liu Y, Chen J, Leng C, Sun Y, Chang D. Pseudorabies virus variant in Bartha-K61-Vaccinated Pigs, China, 2012. Emerg Infect Dis. 2013;19:1749-55.
34. Zhu L, Yi Y, Xu Z, Cheng L, Tang S, Guo W. Growth, physicochemical properties, and morphogenesis of Chinese wild-type PRV Fa and its gene-deleted mutant strain PRV SA215. Virol J. 2011;8:272-272.

35. Tang Y, Liu J, Wang T, An T, Sun M, Wang S, Fang Q, Hou L, Tian Z, Cai X. Live attenuated pseudorabies virus developed using the CRISPR/Cas9 system. Virus Res. 2016;225:33-9.

36. Klupp BG, Hengartner CJ, Mettenleiter TC, Enquist LW. Complete, annotated sequence of the Pseudorabies virus genome. J Virol. 2004;78:424-40.

37. Mettenleiter TC. Immunobiology of pseudorabies (Aujeszky's disease). Vet Immunol Immunopathol. 1996;54:221-9.

38. Van Oirschot JT, Kaashoek MJ, Rijsewijk FAM, Stegeman JA. The use of marker vaccines in eradication of herpesviruses. J Biotechnol. 1996:44:75-81.

39. Tong W, Zheng H, Li G, Gao F, Shan T, Zhou Y, Yu H, Jiang Y, Yu L, Li L. Recombinant pseudorabies virus expressing E2 of classical swine fever virus (CSFV) protects against both virulent pseudorabies virus and CSFV. Antiviral Res. 2020;173:104652.

40. Chen Y, Guo W, Xu Z, Yan Q, Luo Y, Shi Q, Chen D, Zhu L, Wang X. A novel recombinant pseudorabies virus expressing parvovirus VP2 gene: Immunogenicity and protective efficacy in swine. Virol J. 2011;8:307-307.

41. Zhang K, Huang J, Wang Q, He Y, Xu Z, Xiang M, Wu B, Chen H. Recombinant pseudorabies virus expressing P12A and 3 C of FMDV can partially protect piglets against FMDV challenge. Res Vet Sci. 2011;91:90-4.

42. Goatley L, Dixon LK. Processing and Localization of the African Swine Fever Virus CD2v Transmembrane Protein. J Virol. 2011;85:3294-305.

43. Borca MV, Carrillo C, Zsak L, Laegreid WW, Kutish GF, Neilan JG, Burrage TG, Rock DL. Deletion of a CD2-like gene, 8-DR, from African swine fever virus affects viral infection in domestic swine. J Virol. 1998;72:2881-9.

44. Argilaguet J, Perezmartin E, Lopez S, Goethe M, Escribano JM, Giesow K, Keil GM, Rodriguez F. BacMam immunization partially protects pigs against sublethal challenge with African swine fever virus. Antiviral Res. 2013;98:61-5

45. Chen W, Zhao D, He X, Liu R, Wang Z, Zhang X, Li F, Shan D, Chen H, Zhang J. A seven-gene-deleted African swine fever virus is safe and effective as a live attenuated vaccine in pigs. Sci China Life Sci. 2020:1-12.

46. Zhou Y, Sharma J, Ke Q, Landman R, Yuan J, Chen H, Hayden DS, Fisher JW, Jiang M, Menegas W. Atypical behaviour and connectivity in SHANK3 -mutant macaques. Nature. 2019;570:326-31.

47. Hubner A, Petersen B, Keil GM, Niemann H, Mettenleiter TC, Fuchs W. Efficient inhibition of African swine fever virus replication by CRISPR/Cas9 targeting of the viral p30 gene (CP204L). Sci Rep. 2018;8:1449-1449.

48. Cong L, Ran FA, Cox DD, Lin S, Barretto RPJ, Habib N, Hsu P, Wu X, Jiang W, Marraffini LA. Multiplex genome engineering using CRISPR/Cas systems. Science. 2013;339:819-23.

49. Rowlands RJ, Duarte MM, Boinas F, Hutchings G, Dixon LK. The CD2v protein enhances African swine fever virus replication in the tick vector Ornithodoros erraticus. Virology. 2009;393:319-28.

50. Hahn WC, Menu E, Bothwell ALM, Sims PJ, Bierer BE. Overlapping but nonidentical binding sites on CD2 for CD58 and a second ligand CD59. Science. 1992;256:1805-7.

51. Caruso A, Licenziati S, Corulli M, Canaris AD, De Francesco MA, Fiorentini S, Peroni L, Fallacara F, Dima F, Balsari A. Flow cytometric analysis of activation markers on stimulated T cells and their correlation with cell proliferation. Cytometry. 1997;27:71-6.

52. Bianchi ATJ, Moonenleusen HW, Van Milligen F, Savelkoul HFJ, Zwart RJ, Kimman TG. A mouse model to study immunity against pseudorabies virus infection: significance of CD4+ and CD8 + cells in protective immunity. Vaccine. 1998;16:1550-8.

53. Neilan JG, Zsak L, Lu Z, Burrage TG, Kutish GF, Rock DL. Neutralizing antibodies to African swine fever virus proteins p30, p54, and p72 are not sufficient for antibody-mediated protection. Virology. 2004;319:337-42.

\section{Publisher's Note}

Springer Nature remains neutral with regard to jurisdictional claims in published maps and institutional affiliations. 